\title{
Controls on Structural Styles, Basin Development and Petroleum Prospectivity in the Midland Valley of Scotland
}

John R. Underhill *, Alison A. Monaghan ${ }_{2}$ \& Mike A.E. Browne 2

* Corresponding Author:

1 Grant Institute of Earth Science, School of Geosciences, The University of Edinburgh, King's Buildings, West Mains Road, Edinburgh, Scotland, EH9 3JW e.mail: jru@staffmail.ed.ac.uk;

Tel. No: +44 1316508518 (direct line);

Fax No: +441316683184

2 British Geological Survey, Murchison House, West Mains Road, Edinburgh, EH9 3LA e.mail addresses: als@bgs.ac.uk; maeb@bgs.ac.uk

Submitted to Marine \& Petroleum Geology 


\begin{abstract}
Integration of well-calibrated seismic data from the Firth of Forth with field and subsurface data from neighbouring onshore areas provide important new insights into the structural evolution and petroleum habitat in the Midland Valley of Scotland. The results demonstrate that the NNE-SSW striking Midlothian-Leven Syncline, and its flanking Burntisland and D’Arcy-Cousland anticlines, developed as major growth folds during the Late Palaeozoic under a predominantly dextral strike-slip regime. These syn-sedimentary folds controlled depositional thicknesses, facies and dispersal patterns in Early to Late Carboniferous (Viséan-Westphalian) times. Structural geometries suggest that the folds experienced tightening during Late Carboniferous (Variscan) deformation events before being transected by E-W striking dykes and extensional faulting during the Late Carboniferous (Westphalian D) and Early Permian. Although direct evidence for the basin's post-Permian burial history is no longer present, it can be inferred that the area had at least $1 \mathrm{~km}$ of cover prior to Cenozoic uplift.
\end{abstract}

The new understanding of the eastern Midland Valley's structural and subsidence history provides the means by which the occurrence of petroleum in the basin can be explained. It is apparent that the burial of Lower Carboniferous (Dinantian) oil-shale source rocks beneath the Midlothian-Leven Syncline was the primary driver in the maturation and up-dip migration of waxy crude oil into age-equivalent clastic reservoirs located in adjacent anticlines. Initial oil charging is thought to have taken place during the Late Carboniferous, 
was renewed during Mesozoic reburial and appears to continue today despite the effects of significant Cenozoic uplift. In contrast, only small volumes of oil are thought to have been generated by direct contact between the source rocks and igneous intrusions. The new, regional model for oil migration suggests that exploration success in the basin has been governed by the presence of unbreached palaeostructures lying directly up-dip from an oil kitchen, developed in the core of the Midlothian-Leven Syncline during the Late Carboniferous and Mesozoic-Recent stages of burial.

Keywords: Midland Valley; Petroleum Prospectivity; Scotland; oil shale; Carboniferous 


\section{Petroleum Habitat in the Midland Valley}

The Midland Valley of Scotland (MVS) forms a major, $\sim 80 \mathrm{~km}$ wide, $>150-\mathrm{km}$ long WSW-ENE trending, fault-bounded, Late Palaeozoic sedimentary basin that can be traced from Ayrshire and Renfrewshire in the west, through the central belt to the Angus, Perth, Fife and East Lothian coasts in the east (Fig.1). It is believed that the basin extends west to Northern Ireland and eastward to underlie the Forth Approaches (Cartwright et al., 2001).

It has long been recognised that the MVS has petroleum exploration potential (Lees \& Cox, 1937; Lees \& Taitt, 1946). Indeed, it was from West Lothian that the first oil in the UK was extracted in commercial quantities through the mining and distillation of oil-shale (Cameron \& McAdam, 1978; Hallett et al., 1985; Underhill, 2003). The success of the oil-shale industry, occurrence of natural seeps and the recognition of surface anticlines helped to initiate subsurface oil exploration in the basin during the early part of the $19^{\text {th }}$ Century (Lees \& Cox, 1937; Lees \& Taitt, 1946; Selley, 1992).

Political uncertainty immediately prior to the outbreak of the Second World War renewed interest in oil potential in onshore areas of the UK. In the MVS, onshore licenses were awarded to the D'Arcy Exploration Company (which was later to become Anglo-Iranian and eventually BP) and Anglo-American Company (a subsidiary of Standard Oil) along the D'Arcy-Cousland Anticline, which lies some $20 \mathrm{~km}$ east of Edinburgh. Their drilling programme led to the discovery of petroleum 
in Lower Carboniferous, interbedded, fluvio-deltaic and shallow marine clastic reservoirs (now ascribed to the Strathclyde Group), contained within two separate structural culminations along the anticline. In total, around 30,000 barrels of oil and 330 million standard cubic feet of gas were produced from the combined structure, termed the Midlothian Field, before it was abandoned in the late 1960s (Hallett et al., 1985).

Subsequent exploration by Pentex, Burmah Oil and Conoco resulted in the Milton of Balgonie discovery in Fife and the 25/26-1 discovery in the Firth of Forth respectively. Having found a column of oil and numerous oil and gas shows in the 25/26-1 well, Conoco ran three production tests. However, since the oil found within the Early Carboniferous clastic reservoirs proved to be very waxy and near to its pour point, no production was possible and the discovery was considered uneconomic and abandoned.

Despite the long history of oil exploration in the basin, no published models have been proposed to explain its petroleum habitat. The release of well and seismic data from offshore waters of the Firth of Forth and from adjacent onshore areas of Lothian and Fife provides a unique opportunity to document the petroleum system and produce a unifying model to explain the basin’s prospectivity. This has been undertaken primarily through the analysis and interpretation of the structural and stratigraphic elements of the petroleum system within the eastern MVS. When combined with inferences made regarding the basin’s Mesozoic and Cenozoic 
history, the new structural model gives important insights into the controls on petroleum generation in and around the Midlothian-Leven Syncline and provides an explanation for exploration success in the two onshore discoveries at the Midlothian and Milton of Balgonie fields and offshore in the 25/26-1 well (Firth of Forth-1). 


\section{Basin Development}

The MVS developed on the eroded and deformed remnants of the Caledonian Mountains, which had formed as a consequence of the closure and suturing of the Iapetus Ocean (the Caledonian Orogeny) at the end of the Early Palaeozoic (Cameron \& Stephenson, 1985; Glennie \& Underhill, 1998; Read et al., 2002). The basin is bounded to the north-west and south-east by the Highland Boundary Fault System and Southern Upland Fault System respectively (Fig.1), both of which formed important lineaments during the Caledonian Orogeny (Cameron \& Stephenson, 1985; Read et al, 2002). It is the differential weathering of rock units that crop out either side of the two fault systems that has resulted in the morphologically distinct, central lowland belt of Scotland.

The stratigraphy of the MVS consists of a variety of sedimentary, volcanic and igneous rocks. Field mapping has demonstrated that in the eastern MVS, outcrop patterns define several major NNE-SSW striking folds including the Clackmannan, Midlothian and Leven Synclines (each of which contain significant coalfields), which are separated from each other by the intervening Balmule, Burntisland and D'ArcyCousland Anticlines (Cameron \& Stephenson, 1985; Read et al., 2002). Field relations show that the formation of these intra-basinal structures was complete by the end of the Carboniferous since they are cross-cut by a suite of E-W striking, latest Carboniferous-Early Permian dykes, normal faults and extensional fractures (Rippon et al., 1996; Browne \& Woodhall, 1999; Monaghan and Parrish, 2006). Despite the 
fact that Carboniferous rocks occur at outcrop, there is little direct tectonic evidence for any subsequent major tectonic events having affected the area because E-W trending Permian intrusions and faults have remained largely undeformed.

Uncertainty has long surrounded the plate tectonic driving mechanism and the precise kinematics behind Late Palaeozoic basin development in Northern Britain (e.g. Leeder, 1982; Gawthorpe, 1987; Underhill et al., 1988; Haszeldine, 1988; Fraser \& Gawthorpe, 1990; Coward, 1993; Chadwick et al., 1995; Maynard et al., 1997). Controversy has been particularly intense with regard to the Carboniferous evolution of the MVS, which developed within the Caledonian terrane. The basin was originally thought to conform to a classic rift valley comprising a graben that was bounded to the NW and the SE by prominent normal faults (George, 1960). Regional evidence led Leeder (1982) to attribute the development of Late Devonian-Early Carboniferous basins of northern Britain, including the Bowland Basin, Northumberland Trough, Solway Basin and MVS, to a phase of N-S (back-arc) extension and late Carboniferous thermal subsidence.

Subsequent studies contested Leeder's idea and suggested instead that the presence of important intra-basinal N-S striking structures implied that the MVS's formation was the result of E-W tension (Stedman, 1988; Haszeldine, 1988). Their theme of dominantly E-W extension was developed further by Gibbs (1990), who suggested that the basin's internal structure was controlled by a linked family of structures consisting of extensional faults with ramp-flat and listric geometries and steeply- 
dipping transfer faults. In contrast, work built upon subsurface data derived primarily from coal mining activities (e.g. in the Kincardine Basin of Clackmannan) and fieldwork in Fife, led others to propose that strike- or oblique-slip movements may have played a significant role in the development and deformation of the basin (e.g. Read, 1988; McCoss, 1988; Rippon et al., 1996). The notion that transcurrent movement played a role in the tectonic development of the MVS was also promoted by Ritchie et al. (2003) to explain structures recognised beneath the Firth of Forth. 


\section{Basin Stratigraphy}

Integration of field exposures with subsurface data, largely derived from extensive coal mining activity over the past two centuries, has enabled a unifying lithostratigraphic framework to be constructed for the Carboniferous rocks of the MVS (Fig.2; Browne et al., 1999). In the scheme now used, the sedimentary succession is subdivided into four main groups: the Inverclyde, Strathclyde, Clackmannan and Coal Measures groups (Fig.2; Browne et al., 1999). Although component formations may be identified in the Clackmannan and Coal Measures groups, lithological variability and facies changes have meant that a regionally consistent subdivision at formation level has not been possible for the lower two groups. Thus, local formation and member names are still used in West Lothian, East Lothian and Fife (Fig.2).

The bulk of the Lower Carboniferous (lower to middle Mississippian) succession is subdivided into two parts: a lower, Courceyan-Chadian (Tournasian-lower Viséan) Inverclyde Group (INV) and an upper, Asbian-Brigantian (Viséan), Strathclyde Group (SYG). The Inverclyde Group has been subdivided into three formations: the Kinnesswood, Ballagan and Clyde Sandstone Formations (Fig.2). The Strathclyde Group has been separated into ten lithostratigraphic formations, which reflect important facies changes that affected the area during lower to middle Mississippian times. Five of the component formations are recognised in Fife: the Pathhead, Sandy Craig, Pittenweem, Anstruther and Fife Ness Formations (Fig.2) and five in Lothian: 
the West Lothian Oil-Shale, Aberlady, Gullane, Garleton Hills Volcanic and Arthur's Seat Volcanic Formations (Fig.2). In addition, the Kinghorn Volcanic Formation includes the volcanic rocks that occur within the Sandy Craig Formation. Together with the Clyde Sandstone and Ballagan Formations, the component parts of the Strathclyde Group were previously assigned to the Calciferous Sandstone Measures (Greensmith, 1962 \& 1965; Macgregor, 1968; Fig.2).

In Fife and East Lothian, the sedimentary rocks form a significant south-westerly prograding, easterly thickening, sandy clastic, fluvial-deltaic wedge (Greensmith, 1962 \& 1965; Browne \& Monro, 1989). In contrast, coeval sedimentation in parts of West Lothian and the Edinburgh area was dominated by lacustrine oil-shale that has led to the definition of "Lake Cadell" (e.g. Cadell, 1925; Greensmith, 1962 \& 1965). The transition between the two facies types is gradational and, whilst ill-defined, lies on the eastern flank of the Leven Syncline in Fife, where shale-sandstone intercalations predominate. The Viséan algal oil-shales that characterise western parts of the study area (West Lothian Oil-Shale and Gullane formations) have long been considered the most likely source of petroleum in the basin, a suspicion confirmed by biomarker analysis (Raymond, 1991) and reflected in the waxy nature of the crude oil found in well 25/26-1.

The Strathclyde Group is succeeded by the Middle Mississippian-Lower Pennsylvanian Clackmannan Group of Brigantian-Langsettian (Upper ViséanNamurian) age. The Clackmannan Group comprises four formations: the Lower 
Limestone (LLGS), Limestone Coal (LSC), Upper Limestone (ULGS) and the Passage (PGP) formations (Fig.2). Whilst the Lower and Upper Limestone formations represent more marine successions, the Limestone Coal Formation represents a return to predominantly non-marine/paralic deposition from which significant quantities of coal have been extracted. The Passage Formation straddles both the MississippianPennsylvanian and Namurian-Westphalian stage boundaries and marks the upward transition into coal-bearing strata of the Coal Measures Group.

The Coal Measures Group represents the youngest observable sedimentary rocks in the eastern part of the basin. They range up to Middle Pennsylvanian (Westpahlian C; Bolsovian stage) in age and are subdivided into three formations: the Lower (LCMS), Middle (MCMS) and "barren”, Upper Coal Measures formations (UCMS). Although younger Carboniferous deposition is thought to have occurred, no sedimentary rocks of Middle or Upper Pennsylvanian (Westphalian D, Stephanian or Autunian) age are known from the basin and they are presumed to have been eroded during either Late Carboniferous (Variscan) deformation or Paleogene uplift events. Whilst direct evidence for the later uplift event is scarce in the immediate area, the occurrence of Permian and successively younger strata beneath the offshore waters of the Forth Approaches Basin (Thomson, 1978; Cartwright et al., 2001) and the Permian, Mauchline Basin in Ayrshire (Monro, 1999) suggests that the MVS may itself have, once had a significant Permian cover. Evidence from the MVS itself (e.g. Vincent \& Rowley, 2004; Smith, 2005) and from neighbouring areas of the North Sea (e.g. the Inner Moray Firth; Argent et al., 2002) also suggest that the extent of Mesozoic and 
earliest Paleogene sedimentation was more substantive over Scotland in general and the MVS in particular, prior to Paleogene and younger uplift events.

\section{Seismic and Well Database}

This paper primarily focuses upon subsurface (seismic and well) data obtained from the Firth of Forth, which lies between the Fife and Midlothian coastlines and adjacent onshore areas including the Glenrothes area in Fife and parts of Midlothian, SE of Edinburgh (Fig.3). The subsurface data from the region have been used to provide important insights into the development and evolution of structural styles, subcrop patterns and thickness variations in and around one of the most significant intra-basinal folds, the Midlothian-Leven Syncline. When combined with evidence from surface mapping, the seismic interpretation allows the offshore extent of some important onshore faults, such as the Pentland, Crossgatehall and Ardross faults, to be determined (Ritchie et al., 2003), and the trace of previously proposed structures such as the Firth of Forth Fault (Thomson, 1978) to be tested. The data also provide constraints on the nature of the anticlinal marginal folds that lie on the flanks of the main Midlothian-Leven Syncline, namely: the structure tested by the 25/26-1 exploration well; the Earl's Seat Anticline, which was tested by three deep exploration wells (Milton of Balgonie1, -2 and -3$)$; and the Burntisland Anticline. 


\section{Seismic Interpretation}

The seismic database in the Firth of Forth consists of thirty-three, 2-D seismic reflection profiles in an approximate $1 \mathrm{~km} \times 1 \mathrm{~km}$ grid (Figs.3, 5-8) with a combined line-length of nearly $600 \mathrm{~km}$. The seismic data are calibrated by exploration well, 25/26-1 (also sometimes referred to as Firth of Forth-1), drilled by Conoco in 1990, and by eight shallow stratigraphic boreholes (Fig.3), drilled by the Institute of Geological Sciences (now the British Geological Survey) and the National Coal Board (NCB) (Thomson, 1978).

Exploration well 25/26-1 was drilled to a depth of 2009.5m. It entered the Limestone Coal Formation beneath a thin Quaternary cover and proceeded to penetrate the Lower Limestone, Pathhead, Sandy Craig, Kinghorn Volcanic, Pittenweem Formations and Anstruther formations before terminating in the Fife Ness Formation (Fig.4). Correlation of the seismic data to the well and borehole data (Fig.6) allows accurate, contoured top structure maps to be produced for the following six main stratigraphic levels over an area that exceeds $150 \mathrm{~km}^{2}$ :

Top Passage Formation (which also represents the Top Clackmannan Group and Base Coal Measures Group);

Top Upper Limestone Formation;

Top Lower Limestone Formation;

Top Pathhead Formation (Top Strathclyde Group); 
Top Sandy Craig Formation;

Base Pittenweem Formation (equivalent to the Base West Lothian Oil Shale

Formation;

Top Anstruther Formation; Fig.6);

The WSW-ESE trending seismic lines from Conoco's survey provide representative cross-sections across the offshore extent of the Midlothian-Leven Syncline and demonstrate that the structure represents a NNE-SSW striking, symmetrical, open synclinal fold (Figs.5, 6, 7). Both limbs of the synclinal structure are either, steeplydipping and undeformed (as in Fig.5), or locally kinked and broken by steeplyinclined, inward-verging folds or faults. Significantly, each of the seismicstratigraphic packages is characterised by internal thickening towards the synformal axis and pronounced onlap towards its flanks (Figs. 5, 6, 7), thus demonstrating the importance of syn-sedimentary growth in the development of the fold from the Middle Mississippian into the Middle Pennsylvanian (mid-late Viséan to Westphalian times).

The eastern flank of the main syncline is dominated by a broad open anticline on which smaller parasitic folds are superimposed, one of which formed the target for well 25/26-1 (Figs. $6 \&$ 7). At depth, the broad anticline appears to converge and may be cut by upward-divergent steeply-dipping fault planes that branch from a central zone of deformation (Fig.6). As such, the folding exhibited by the offshore seismic data is analogous in size and structural character to the small parasitic folding that has 
been described from cross-sections across the onshore folds in an analogous position (i.e. the D'Arcy-Cousland Anticline; Hallett et al., 1985). The geometries displayed by seismic and onshore structures directly along-strike, are consistent with flower structures found along transcurrent faults (Harding, 1985; Naylor et al., 1986; Richard et al., 1995).

In the eastern-most part of the survey, it is evident that the component parts of the Strathclyde Group (e.g. the Anstruther Formation) show evidence of divergence to give the appearance of an easterly-thickening sedimentary wedge (Figs.6 \& 7). Although no clinoform geometries are apparent, the overall geometry of the Strathclyde Group is consistent with field observations along the Fife coast, and are interpreted to form part of a major, westerly-prograding wedge of fluvio-deltaic sediments built out into a lacustrine environment dominated by oil-shales (Greensmith, 1962 \& 1965).

As well as enabling top structure and isochore maps to be constructed (e.g. Fig.9), the seismic interpretation also allows subcrop patterns to be determined. These can be combined with onshore data to allow the Midlothian-Leven Syncline to be traced across the Firth of Forth (Fig. 10). The mapping demonstrates that the axis of the Midlothian-Leven Syncline is S-shaped with two, separate NNE-SSW trending lows separated by a pronounced saddle (e.g. Fig. 8). The core of the more northerly Leven Syncline lies approximately $5 \mathrm{~km}$ east of Kirkcaldy and the core of the Midlothian Syncline lies 5km south-east of the Portobello district of Edinburgh. Subcrop of the 
Middle Coal Measures replaces the Upper Coal Measures over the culmination defined between two synclines (Fig. 10).

Significantly, no evidence has been found for either the continuation of the Pentland or Ardross faults or for the existence of pervasive E-W trending Permian faults within the survey. Furthermore, in agreement with Ritchie et al. (2003), there now seems to be absolutely no seismic evidence for the previously proposed Firth of Forth Fault in the area (cf. Thomson, 1978). 


\section{Structural and Stratigraphic Relationships in Fife and the Lothians}

Geological and geophysical data obtained from the onshore areas that surround the Firth of Forth can be used to further develop an understanding of the structural development and stratigraphic evolution of the MVS. In the next section, key localities in Fife and East Lothian are examined which supplement the seismic interpretation. The integration with the subsurface data allows their significance with regard to basin development to be deduced.

\subsection{Earl's Seat Anticline, Glenrothes, Fife}

The availability of fifteen 2-D seismic lines (shot in the 1980s by Pentex, Burmah Oil and Anvil; Fig.3) provides the basis for determining the structure beneath the Earl's Seat Anticline (Fig.11) and Thornton-Balgonie Syncline, south-westerly plunging folds, formed on the western limb of the broader Midlothian-Leven Syncline (Fig.10). The seismic data are calibrated by three exploration boreholes (Milton of Balgonie-1, -2 and -3), drilled between 1985 and 1988 by Burmah Oil and Pentex (Fig.3). Use has also been made of four other deep boreholes (Balfour G1-4), which were drilled in 1938 and 1939 by D'Arcy, twenty other stratigraphic boreholes drilled to depths greater than 100m (Fig.3), mine abandonment plans, opencast coal site records and field mapping, all of which reside in the BGS data stores. 
The seismic data demonstrate that a series of en-echelon N-S and NNE-SSW trending contractional (reverse) faults characterise the Earl's Seat Anticline at depth (Fig. 12). The structures appear to steepen with depth, are curved in plan-view and bound the anticlinal crest. Importantly, interpretation of the seismic data demonstrates that Middle Mississippian-Lower Pennsylvanian (Viséan and Namurian) strata (up to and including the Upper Limestone Formation) show a progressive easterly thickening towards the Midlothian-Leven Syncline (Fig. 12). Data from BGS archived boreholes drilled to the south of the Leven Fault confirm that interpretation with the Upper Limestone Formation thickening from $<300 \mathrm{~m}$ in the Thornton-Balgonie Syncline, to between 300 and 500m thick over the Earl's Seat Anticline and >600m in thickness on the western limb of the Midlothian-Leven Syncline.

The integration of the subsurface data with field relations in the Glenrothes area implies that the Midlothian-Leven Syncline initially grew as a large-scale regional structure during Viséan-Namurian times and was tightened thereafter. In contrast, the data demonstrate that the Earl's Seat Anticline and Thornton-Balgonie Syncline formed after the Namurian wholly as a result of post-depositional (Variscan) contractional deformation. All of the folds are cut by several, E-W trending normal faults (Figs.10 \& 11) that formed after deposition of sedimentary rocks of Middle Pennsylvanian (Westphalian C) age, probably as a result of latest Carboniferous Early Permian extension. 


\subsection{Burntisland Anticline}

The Burntisland Anticline is a broad arch over $20 \mathrm{~km}$ wide whose ill-defined axis appears to strike approximately N-S but is deflected towards the NE as it approaches the surface trace of the East Ochil Fault (Fig.10, 13). It forms the western flank of the Midlothian-Leven Syncline and the eastern side of the Lochore Syncline (Fig.1). The structure is coincident with the outcrop of the Kinghorn Volcanic Formation (Fig. 10). Whilst Francis (1991) invoked a basement control on its formation, MacGregor (1996) records that the anticline is associated with a persistent area of reduced subsidence from the lower Strathclyde Group to deposition of the Passage Formation and estimated the thicknesses for this lithostratigraphic interval to be $>676 \mathrm{~m}$ on the Burntisland Anticline as opposed to $1963 \mathrm{~m}$ in the Leven Syncline. What is apparent from the structural dips is that the anticline was accentuated by Late Carboniferous (Variscan) contractional deformation. Unfortunately, only limited borehole and very little seismic data exist to help constrain the deeper structure of the anticline.

\subsection{Westfield Basin, Fife}

The Westfield Basin is a small (2km wide) SW-NE striking syncline containing Upper Mississippian-Middle Pennsylvanian (Namurian and Westphalian) sedimentary rocks that lies to the NNW of the Burntisland Anticline (Fig.13) and is transected by the East Ochil Fault on its northern side (Fig.10 \&13). The basin contains coal-bearing strata that have largely been extracted by opencast methods. 
Field observations obtained during the course of opencast mine activities provide important information regarding the development and evolution of the basin.

Structures in the coal-bearing Lower Pennsylvanian (Namurian-Westphalian A) Passage Formation provide spectacular evidence that the Westfield Basin was an important syn-sedimentary growth fold (Fig.14). Over a distance of about 250m, strata are seen to thicken by over $400 \%$ into the core of the syncline (from $28 \mathrm{~m}$ on its flanks to $130 \mathrm{~m}$ in its core; Brand et al., 1980). The geometry is similar to that seen on a larger scale in the Firth of Forth (e.g. Fig.6).

E-W trending normal faulting controlled the dissection of the syncline (e.g. the East Ochil Fault; Figs.13 \& 15). Significantly, evidence that footwall strata are not baked by the adjacent Midland Valley quartz-dolerite sill complex at Westfield (Browne \& Woodhall, 1999; Fig. 15) implies that here, unlike the West Ochil Fault at Stirling, further extensional activity post-dated igneous intrusion and can thus be interpreted as latest Carboniferous or younger in age.

\subsection{Ardross, Fife}

NNE-SSW striking folding also affects Middle-Upper Mississippian (Upper Viséan and Lower Namurian) strata that occur to the east of the Midlothian-Leven Syncline, along the East Neuk coastline of SE Fife between Elie and Anstruther (Fig.16; Forsyth \& Chisholm, 1977). The structures form a suite of spectacular folds such as 
the St Monans Syncline (Fig.17) that lie adjacent to, and are transected by, a series of SW-NE striking wrench faults along which Upper Pennsylvanian (Stephanian) volcanic necks and dykes were intruded (Forsyth \& Rundle, 1978). Their orientation is consistent with transpressional folds generated adjacent to strike-slip faults in analogue models (e.g. Wilcox et al., 1973) and field-based studies of transcurrent faults (e.g. Sylvester, 1988). It has been suggested that the disposition of the structures is consistent with a phase of post-depositional dextral transpression having occurred along the Ardross Fault (Cumming, 1936; McCoss, 1988).

\subsection{East Lothian}

The expression of the Midlothian-Leven Syncline may be traced onshore (Figs.10 \& 18). The D'Arcy-Cousland and Herbershaw anticlines form its south-eastern flank and the Pentland Fault, defines and transects its north-western margin (Tulloch \& Walton, 1958). The Midlothian Syncline, which actually consists of two synclinal folds offset from each other (i.e. the Penicuik and Midlothian Synclines; Fig.10), contains the highly productive Midlothian Coalfield (Tulloch \& Walton, 1958). Significantly, isopach maps demonstrate that the original Carboniferous depositional axis runs obliquely to the present one (Goodlet, 1957; Tulloch \& Walton, 1958), thus implying that significant post-depositional tightening occurred in addition to demonstrable syn-sedimentary growth. 
The Pentland Fault may be traced onshore for over $45 \mathrm{~km}$ to its branch point with the Southern Upland Fault. For most of its length it juxtaposes Carboniferous and SiluroDevonian (Old Red Sandstone) rocks implying a throw of >>1km (Fig.10; BGS, 2003). However, displacement diminishes progressively to the north east and Carboniferous rocks lie either side of the fault towards the Firth of Forth coast (Fig.18). Field relations along its trace demonstrate that the Carboniferous strata on its eastern (footwall) side are tilted to vertical or locally overturned (BGS 2003; Fig.18), consistent with the structure forming a north-westerly dipping, steep, reverse fault (Peach et al., 1910; McLintock \& Phemister, 1929; Lees \& Taitt, 1946).It has been suggested that the last phase of movement on the Pentland Fault occurred after Permo-Carboniferous events, which is thought by some to have involved sinistral wrench movement (e.g. Anderson, 1951).

Surface data demonstrate that the D'Arcy-Cousland Anticline is a NNE-SSW striking elongate, slightly asymmetric pericline. Subsurface data have demonstrated that the structure, which affects Middle Mississippian-Lower Pennsylvanian (Viséan and Namurian) strata, lies above a series of downward-convergent, steep, post-depositional reverse faults (Hallett et al., 1985; see their fig.3) suggesting that it has a similar structural genesis to the Earl's Seat structure in Fife.

Like other areas of the MVS, the Midlothian Syncline is transected by a series of E-W striking dykes and normal faults that cross-cut and offset late Carboniferous strata. Whilst their last movement was evidently post-depositional, there is some evidence from geophysical data (Hipkin pers comm., 2004) and boreholes that at least one of the major 
normal faults, the Roslin-Vogrie Fault (Fig. 10) also had syn-sedimentary activity on it during the Carboniferous (Fig. 19).

In contrast to the Westfield Basin where intrusion of latest Carboniferous- Early Permian quartz-dolerite pre-dated E-W faulting, to the east of Edinburgh E-W striking quartz-dolerite dykes cut across and thus post-date E-W striking faults (BGS 2003), consistent with linked latest Carboniferous- Early Permian intrusion and extension at the regional scale. 


\section{Structural Controls on the Development of the Midland Valley of Scotland}

Integration of the subsurface and outcrop data affords the opportunity to test previous hypotheses and produce the following, new model which details the Middle to Late Carboniferous, Permian and post-Permian tectonic history of the MVS. The results allow us to extend the work of Ritchie et al. (2003) by considering the basin in its regional context from offshore to surrounding onshore areas and provide new constraints on the structural development of the MVS.

\subsection{Mid-late Carboniferous Evolution}

Syn-sedimentary growth from the Middle Mississippian to the Middle Pennsylvanian (Late Viséan-Westphalian) characterises the Midlothian-Leven Syncline and is inferred to have occurred during the development of the NNE-SSW striking Clackmannan Syncline to the west (e.g. Read, 1988, Rippon et al., 1996; Hooper, 2003). This development of synsedimentary folds at high angles to the active NE-SW striking, fault-bounded basin margins is characteristic of subsiding strike- or oblique-slip structural settings. Comparison with sandbox models, which have replicated field observations and structural analogues are both consistent with the synclines having developed within an overall dextral strike-slip regime (Wilcox et al., 1973; Fig.19). 
Independent evidence in support of a dextral strike-slip origin for Late Carboniferous structural styles in MVS comes from the nature of some of the coeval igneous material in the basin, much of which has a very unusual character. In particular, the unique record of mantle xenoliths is thought to indicate their derivation from deep-seated, sub-vertical fault zones that, unlike faults that commonly characterise extensional and contractional settings, transect the crust to tap a mantle source (Macintyre et al., 1981).

Tightening of folds and the occurrence of steeply-inclined reverse faults (e.g. the Pentland Fault) and faults with a notably strike- or oblique-slip component on them (e.g. the Ardross Fault) affecting sedimentary rocks belonging to the Coal Measures Group imply that the Midlothian-Leven Syncline continued to tighten during the late Carboniferous. Vincent and Rowley (2004) estimate that $>0.4 \mathrm{~km}$ of sediment was removed from the Firth of Forth area and c. $0.7 \mathrm{~km}$ was eroded from the Milton of Balgonie area as a result of Variscan uplift.

The tightened folds probably occurred either as a result of the continued, long-lived effects of the dextral shear process or through added complexity due to transpressional deformation resulting from the effects of deformation across the Variscan foreland (e.g. Underhill et al., 1988; Corfield et al., 1996; Glennie \& Underhill, 1998), which are believed by some to reach northern Scotland (e.g. Easter Ross and the Inner Moray Firth; Underhill \& Brodie, 1993). A dextral strike-slip control on the development and evolution of the MVS at this time is consistent with structural relations seen in basins that formed along the eastern seaboard of North America during the Carboniferous (Belt, 1969). 


\subsection{Latest Carboniferous-Permian deformation}

Late Carboniferous sedimentary rocks are cut by numerous E-W striking faults and quartzdolerite dyke swarms dated at Latest Carboniferous (Stephenson et al., 2003; Monaghan \& Parrish 2006). Their occurrence, allied to the lack of evidence for continued differential subsidence in the synformal depocentres, demonstrates that dextral strike-slip had been replaced by N-S tension by latest Carboniferous and early Permian times, probably in response to the opening of the Northern and Southern Permian Basins that now underlie the North Sea (Glennie \& Underhill, 1998).

Although it is hard to discern whether extensional faulting resulted in the formation of major Permian basins in the immediate area, circumstantial evidence suggests that such basins may have developed. Firstly, fault-controlled Permian basins occur elsewhere in Southern Scotland (e.g. Ayrshire; Mykura et al., 1967) or have been proposed (e.g. on the southern side of the Ochil Fault; Rippon et al., 1996). Secondly, carbonaceous lithologies in the Coal Measures have reached bituminous grade, implying burial to significant depths after deposition. Anthracite grade coal is only seen next to sills (Macgregor \& Macgregor, 1948) and vitrinite reflectance analyses on samples found distant from intrusions indicate relatively high ranks (c.0.7-0.9\%VR, Raymond 1991). 


\subsection{Post-Permian History}

Subcrop patterns in the Forth Approaches Basin, that lies to the east of the Firth of Forth, are consistent with evidence from other areas that suggest that the British Isles experienced increasing amounts of regional uplift during the Paleogene towards the west (best documented in the Inner Moray Firth; Hillis et al., 1994). It seems plausible that any postCarboniferous sedimentary rocks were removed during this event. Support for this proposal comes from thermal modelling studies around the Midlothian-Leven Syncline that imply burial of Carboniferous strata by up to $2 \mathrm{~km}$ prior to Cenozoic uplift (Vincent \& Rowley, 2004) and from unpublished fission track results (e.g. from the 25/26-1 well), which suggest that $>1.3 \mathrm{~km}$ of sedimentary cover has been removed from the area (Green, pers. comm., 2000). Some structural reactivation of the basin-bounding and intrabasinal faults (such as the Pentland Fault) may have occurred during later events (e.g. Early Cenozoic uplift; Anderson, 1951). 


\section{Implications for Petroleum Prospectivity}

Integration of the new structural and stratigraphic data with the sedimentary record provides important new insights into the controls on the petroleum system in the eastern MVS. The results extend the understanding of the Carboniferous reservoir plays from previous studies that have focused upon the east Midlands, northern England and the Southern North Sea (Fraser \& Gawthorpe, 1990; Corfield et al., 1996).

\subsection{Elements of the Petroleum System}

The MVS evidently contains all the main ingredients to make a petroleum province in that it has a rich source rock (the Strathclyde Group oil shales, see section 3), potential reservoirseal pairs (in interbedded sedimentary rocks of the Strathclyde Group) and well defined anticlinal trapping geometries present (Fig. 23). However, whilst the presence of an active oil seep along the Pentland Fault, at St. Catherine's Well, in the Liberton area of Edinburgh (Fig.20), the production of hydrocarbons from the Midlothian Field, and the occurrence of oil in well 25/26-1 well and the Milton of Balgonie discovery, all clearly attest to source rock maturation and petroleum migration having occurred at some time in the basin, key questions remain regarding the genesis, timing and extent of petroleum maturation and migration.

Raymond and Murchison (1988) showed that local heating of source rocks adjacent to igneous intrusions was important locally. Murchison and Raymond (1989) proposed that, 
along with burial history, widespread igneous activity was significant in the organic maturation of coals. However, integration of the seismic interpretation presented here with the field data provide support for an exclusive burial-related explanation for petroleum generation in the basin.

Evidence from surface sampling of the potential source rocks suggests that whilst they locally approach the threshold for liquid hydrocarbon generation, they are all immature at outcrop. However, the occurrence of good quality bituminous coals in the Midlothian and Fife coalfields, together with geochemical analyses of samples from the BGS shallow borehole 73/16, and well 25/26-1 show that units within the Strathclyde Group lie close to the oil window. Since both boreholes were drilled in structurally elevated positions on the flanks of the main syncline, the obvious conclusion is that oil-shales within the Strathclyde Group sited in the core of the synclines, which were buried much more deeply, have at some time heated sufficiently to mature and become oil-bearing (Fig.21). Construction of schematic burial curves for the highly productive West Lothian Oil Shale Formation for various positions in and around the Midlothian-Leven Syncline demonstrates the effect that their respective differential subsidence histories had for source rock maturation and suggests that maturation is largely restricted to the core and flanks of the fold (Fig.21).

It appears from the burial histories that initial maturation and petroleum charge may have occurred during the Carboniferous prior to Variscan uplift. This is in agreement with Raymond \& Murchison (1989) who proposed that the current level of vitrinite maturation was reached prior to sill intrusion at $295 \mathrm{Ma}$. As in other areas of the UK (e.g. east 
Midlands; Fraser \& Gawthorpe, 1990), however, the effects of subsequent Mesozoic and earliest Paleogene burial appear to have been crucial in promoting renewed charge into prospective structures.

Extrapolation of a typical geothermal gradient recorded from the region are in the order of 26 degrees $\mathrm{C} / \mathrm{km}$ (e.g. in well 25/26-1) suggests that petroleum generation may continue in deeper parts $(>3.25 \mathrm{~km})$ of the Midlothian-Leven Syncline today. The extent of the presentday kitchen area can be deduced from the seismic interpretation (e.g. Fig 9) and appears to cover an area of $>25$ sq.km (Fig.22). Importantly, since deeper burial of the Strathclyde Group oil-shales is implied prior to Paleogene uplift, the effective kitchen area and hence, palaeo oil migration into neighbouring structures would certainly have been much more extensive during the Cretaceous and Early Paleogene.

\subsection{Remaining Potential}

Prospectivity in and around the Midlothian-Leven Syncline is enhanced by the occurrence of anticlinal folds adjacent to, up-dip from, and in direct communication with the deeply-buried, mature, source rocks. Consequently, exploration potential might be expected in any culmination located along the length of the neighbouring long-lived, intrabasinal anticlinal folds. However, the fact that the sedimentary facies within the Strathclyde Group becomes more sand-rich towards its easterly, proximal source (Greensmith, 1965), suggests that the eastern flanking structures (e.g. 25/26-1 and the D'Arcy-Cousland anticline) would have 
better reservoir potential than the axis of the Burntisland Anticline. Indeed, this may explain why the Midlothian Field produced commercial quantities of oil and gas whilst those discoveries sited farther west have not.

Whilst potential exists to develop the 25/26-1 and Milton of Balgonie discoveries or to drill other folds containing suitable clastic reservoirs around the Midlothian-Leven kitchen, any structures are likely to be relatively small. Instead, the greater value of understanding the petroleum habitat in the MVS may be to elucidate the petroleum exploration potential in Devono-Carboniferous folds lying buried beneath the Forth Approaches to the east (Cartwright et al., 2001).

Finally, the new model of the petroleum system which governs plays in the MVS presented herein may also be a good structural analogue for basins lying along the eastern seaboard of North America (e.g. Nova Scotia and Newfoundland; Belt, 1969), where exploration activity is currently taking place. 


\section{Conclusions}

Integration of subsurface data with outcrop information and strategic field localities has helped resolve the long-standing controversy regarding the structural controls on the MidLate Carboniferous development and evolution of the MVS. The data are consistent with the basin forming as a result of progressive dextral strike-slip along its basin-bounding Highland Boundary and Southern Upland fault systems during late Viséan to Westphalian times.

Internal deformation consequent upon wrench motion on the basin margins, led to differential subsidence and the progressive development of several NNE-SSW striking synsedimentary growth folds, the most prominent of which was the Midlothian-Leven Syncline. Burial in the axis of that important fold resulted in maturation of and derivation of petroleum from oil-shale source rocks belonging to the Strathclyde Group and migration of oil out from its core during the Late Carboniferous. Despite being affected by subsequent Variscan and Paleogene uplift events, Permian to earliest Paleogene burial appears to have been sufficient to permit further petroleum maturation in the axis of the syncline that continues at the present-day despite the effects of Paleogene regional uplift and an easterly tilt being emparted on the basin. The main successful play type consists of the up-dip migration and charge of flanking palaeostructures, such as the D'Arcy-Cousland and Earl's Seat Anticlines and the culmination drilled by well 25/26-1. Further untested petroleum potential appears to exist in analogous fold structures located beneath a Permian and younger cover sequence in the Forth Approaches to the east. 


\section{Acknowledgements}

We acknowledge Conoco UK Ltd. for access to and permission to publish sections from their seismic and well data and thank Steve Daines and Jim Farrell for their enthusiastic support of the studies reported herein. Alison Monaghan and Mike Browne publish with the permission of the Executive Director of the British Geological Survey. Seismic interpretation was carried out using Geoquest iesx software, which was kindly provided by Sclumberger GecoPrakla, on workstations housed in The University of Edinburgh's seismic interpretation laboratory. We thank Maxine Akhurst and Chris Thomas (BGS) and Al Fraser (BP Exploration) for their helpful reviews of the manuscript. 


\section{References}

Anderson, E.M. 1951. The Dynamics of Faulting and Dyke Formation with Applications to Britain. 2nd Edition. Edinburgh.

Argent et al., 2002

Belt, E.S. 1969. Newfoundland Carboniferous stratigraphy and its relation to the Maritimes and Ireland. In: North Atlantic; geology and continental drift. AAPG Memoir, 12, 734-753.

BGS 1971a. Sheet 41 North Berwick solid edition. British Geological Survey. Scotland 1:50 000 series

BGS 1971b. Sheet 40 Kinross solid edition. British Geological Survey. Scotland 1:50 000 series

BGS 1980. Sheet 33E Dunbar solid edition. British Geological Survey. Scotland 1:50 000 series

BGS 1983. Sheet 33W Haddington solid edition. British Geological Survey. Scotland 1:50 000 series 
BGS 1996. Kinglassie NT29NW solid edition. British Geological Survey. Scotland 1:10 000 series

BGS 1998. Sheet 32W Livingston solid edition. British Geological Survey. Scotland 1:50 000 series

BGS 1999. Sheet 40E Kirkcaldy solid edition. British Geological Survey. Scotland 1:50 000 series

BGS 2003. Sheet 32E Bedrock Edinburgh 1:50 000 scale.

Brand, P.J., Armstrong, M. \& Wilson, R.B. 1980. The Carboniferous strata at the Westfield opencast site, Fife, Scotland. Report of the Institute of Geological Sciences (79/11). HMSO London. ISBN 0118841238

Browne, M.A.E. \& Monro, S.K. 1989. Evolution of the coal basins of Central Scotland: In Congres International de Stratigraphie et de Geologie du Carbonifere 11th 1987 Beijing; Nanjing University of Press; 1-19.

Browne, M.A.E. \& Woodhall, D.G. 1999. Geology of the Kirkcaldy district - a brief explanation of the geological map. Sheet Explanation of the British Geological Survey, 1:50 000 Series. Sheet 40E (Scotland). 
Browne, M.A.E., Dean, M.T., Hall, I.H.S., McAdam, A.D., Monro, S.K. \& Chisholm, J.I. 1999. A lithostratigraphical framework for the Carboniferous rocks of the Midland Valley of Scotland. British Geological Survey Research Report, RR/99/07.

Cadell, H.M. 1925. The rocks of west Lothian: an account of the geological and mining history of the west Lothian district. (Edinburgh: Oliver and Boyd.).

Cameron, I.B. \& McAdam, A.D. 1978. The oil-shales of the Lothians, Scotland: present resources and former workings. Report of the Institute of Geological Sciences $78 / 28$.

Cameron, I.B. \& Stephenson, D. 1985. British regional geology: the Midland Valley of Scotland. (3rd edition). HMSO, London for the British Geological Survey.

Cartwright, J., Stewart, S. \& Clark, J. 2001. Salt dissolution and salt-related deformation of the Forth Approaches Basin, UK North Sea. Marine and Petroleum Geology, 18, 757778

Chadwick, R.A, Holliday, D.W, Holloway, S. \& Hulbert, A.G. 1995. The structure and evolution of the Northumberland-Solway Basin and adjacent areas. Subsurface Memoir of the British Geological Survey. 
Corfield, S.M, Gawthorpe, R.L, Gage, M, Fraser, A.J, \& Besly, B.M. 1996. Inversion tectonics of the Variscan foreland of the British Isles. Journal of the Geological Society, London, 153, 17-32.

Coward, M.P. 1993. The effect of Late Caledonian and Variscan continental escape tectonics on basement structure, Palaeozoic basin kinematics and subsequent Mesozoic basin development in N W Europe. In: Parker, J R (Ed.) Petroleum Geology of Northwest Europe: Proceedings of the 4th Conference. (London: The Geological Society). 1095-1108.

Cumming, G.A. 1936. The structural and volcanic geology of the Elie-St Monance district, Fife. Transactions of the Edinburgh Geological Society, 13, 340-365.

Forsyth, I.H, \& Chisholm, J.I. 1977. The Geology of East Fife. Memoir of the Geological Survey of Great Britain, Sheet 41 and part of 49 (Scotland).

Forsyth, I.H, \& Rundle, C.C. 1978. The age of the volcanic and hypabyssal rocks of East Fife. Bulletin of the Geological Survey of Great Britain, No. 60, 23-29.

Francis, E.H. 1991. Carboniferous. In: Craig, G.Y. (ed.): Geology of Scotland (3 ${ }^{\text {rd }}$ Edition). Geological Society, London, 347-392. 
Fraser, A.J \& Gawthorpe, R.L. 1990. Tectono-stratigraphic development and hydrocarbon habitat of the Carboniferous in northern England. In: Hardman, R.F.P. \& Brooks, J. (Eds.). Geological Society, London, Special Publications, 55: 49 - 86.

Gawthorpe, R.L. 1987. Tectono-sedimentary evolution of the Bowland Basin, N England, during the Dinantian. Journal of the Geological Society, 144, 59-71.

George, T.N. 1960. The stratigraphic evolution of the Midland Valley. Transactions of the Geological Society of Glasgow, 24, 32-107.

Gibbs, A.D. 1990. Linked fault families in basin formation. Journal of Structural Geology, 12, 795-803.

Glennie, K.W. \& Underhill J.R. 1998. Origin, development and evolution of structural styles. In Glennie, K.W. (Ed.): Petroleum Geology of the North Sea: Basic Concepts and Recent Advances. 42-84.

Goodlet, G.A. 1957. Lithological variation in the Lower Limestone Group of the Midland Valley of Scotland. Bulletin of the Geological Survey of Great Britain, 12, $52-65$.

Greensmith, J.T. 1962. Rhythmic deposition in the Carboniferous oil-shale group of Scotland: Journal of Geology 70, 355-364 
Greensmith, J.T. 1965. Calciferous Sandstone Series sedimentation at the eastern end of the Midland Valley of Scotland. Journal of Sedimentary Research, 35, 223-242

Hallett, D., Durant, G.P. \& Farrow, G.E. 1985. Oil exploration and production in Scotland. Scottish Journal of Geology, 21, 547-570.

Harding, T.P. 1985. Seismic characteristics and identification of negative flower structures, positive flower structures and positive structural inversion. AAPG Bulletin, 69, 582-600.

Haszeldine, R.S. 1988. Crustal lineaments in the British Isles: their relationship to Carboniferous basins. In: Besly, B M, and Kelling, G (Eds.): Sedimentation in a synorogenic basin complex: the Upper Carboniferous of northwest Europe. 53-68. (Glasgow: Blackie and Son.)

Hillis, R.R, Thomson, K. \& Underhill, J.R. 1994. Quantification of Tertiary erosion from the Inner Moray Firth using sonic velocity data from the Chalk and Kimmeridge Clay. Marine and Petroleum Geology, 11, 283-293.

Holliday, D.W. \& Molyneux, S.G. 2006. Editorial Statement: New official names for the subsystems, series and stages of the Carboniferous System, Proceedings of the Yorkshire Geological Society, 56, 57-58. 
Hooper, M.D. 2003. The Carboniferous Evolution of the Central Coalfield Basin, Midland Valley of Scotland. Unpublished PhD thesis, University of Leicester 166pp.

Leeder, M.R. 1982. Upper Palaeozoic basins of the British Isles - Caledonian inheritance versus Hercynian plate marginal processes. Journal of the Geological Society of London, 139, 479-491.

Lees, G.M. \& Cox, P.T. 1937. The geological basis for the search for oil in Great Britain by the D'Arcy Exploration Co. Ltd. Quarterly Journal of the Geological Society, 93, 156-90.

Lees, G.M. \& Taitt, A.H. 1946. The geological results of the search for oilfields in Great Britain. Quarterly Journal of the Geological Society, 101, 255-317.

Macintyre, R.M, Cliff, R.A. \& Chapman, N.A. 1981. Geochronological evidence for phased volcanic activity in Fife and Caithness necks, Scotland. Transactions of the Royal Society of Edinburgh: Earth Sciences, 72, 1-7.

MacGregor, A.R. 1996. Fife and Angus geology. An excursion guide. (3rd Edition). (Edinburgh: The Pentland Press). 
Macgregor, M \& Macgregor, A.G. 1948. The Midland Valley of Scotland. $2^{\text {nd }}$

Edition. British Regional Geology. Geological Survey.

McCoss, A.M. 1988. Restoration of transpression/ transtension by generating the three-dimensional segmented helical loci of deformed lines across structure contour maps. Journal of Structural Geology, 10, 109-120.

McLintock, W.F.P. \& Phemister, J. 1929. A Gravitational Survey over the Pentland Fault, near Portobello, Midlothian, Scotland. Sum.Prog.Geol.Surv. for 1928, 10-28.

Maynard, J.R., Hofmann. W., Dunay, R.E., Bentham. P.N., Dean, K.P. \& Watson, I. 1997. The Carboniferous of Western Europe: the development of a petroleum system. Petroleum Geoscience, 3, 97-115.

Monaghan, A.A. \& Parrish R.R. 2006. Geochronology of Carboniferous-Permian volcanism in the Midland Valley of Scotland: implications for regional tectonomagmatic evolution and the numerical timescale. Journal of the Geological Society of London, 163, 15-28.

Monro, S.K. 1999. Geology of the Irvine district. Memoir of the British Geological Survey, Sheet 22W and part of Sheet 21E (Scotland). 
Murchison, D.G. \& Raymond, A.C. 1989. Igneous activity and organic maturation in the Midland Valley of Scotland. International Journal of Coal Geology, 14, 47-82.

Mykura, W., Calver, M. A. \& Wilson, R. B. 1967. The Upper Carboniferous rocks of south-west Ayrshire. Bulletin of the Geological Survey of Great Britain, 26, 23-98.

Naylor, M.A., Mandl, G \& Sijpesteijn, C.H.K.1986. Fault geometries in basementinduced wrench faulting under different initial stress states. Journal of Structural Geology, 8, 737-752.

Peach, B.N., Clough, C.T., Hinxman, L.W., Grant Wilson, J.S., Crampton, C.B., Maufe, H.B. \& Bailey, E.B. 1910. The Geology of the Neighbourhood of Edinburgh. $2^{\text {nd }}$ Edition. Mem Geol.Surv.

Raymond, A.C. \& Murchison, D.G. 1988. Development of organic maturation in the thermal aureoles of sills and its relation to sediment compaction. FUEL, 67, 15991608.

Raymond, A.C. \& Murchison, D.G. 1989. Organic maturation and its timing in a Carboniferous sequence in the central Midland Valley of Scotland: comparisons with northern England. FUEL, 68, 328-334. 
Raymond, A.C. 1991. Carboniferous rocks of the Eastern and Central Midland Valley of Scotland: organic petrology, organic geochemistry and effects of igneous activity. Unpublished Ph.D Thesis, University of Newcastle upon Tyne

Read, W.A. 1988. Controls on Silesian sedimentation in the Midland Valley of Scotland. 222-241 in Sedimentation in a synorogenic basin complex: the Upper Carboniferous of northwest Europe. Besly, B M, and Kelling, G (Eds.). (Glasgow: Blackie and Son.).

Read, W.A., Browne M.A.E., Stephenson D. \& Upton B.J.G. 2002. Carboniferous. In Trewin N.H. (ed) The Geology of Scotland. Fourth Edition. The Geological Society, London, 251-300.

Richard, P.D., Naylor, M.A. \& Koopman, A. 1995. Experimental Models of Strike Slip Tectonics. Petroleum Geoscience, 1, 71-80.

Rippon, J., Read, W.A, \& Park, R.G. 1996. The Ochil Fault and the Kincardine basin: key structures in the tectonic evolution of the Midland Valley of Scotland. Journal of the Geological Society, London, 153, 573-587.

Ritchie, J.D., Johnson, H., Browne, M.A.E. \& Monaghan A.A. 2003. Late DevonianCarboniferous tectonic evolution within the Firth of Forth, Midland Valley, as revealed from 2D seismic reflection data. Scottish Journal of Geology, 39, 121-134. 
Selley, R.C. 1992. Petroleum seepages and impregnations in Great Britain. Marine and Petroleum Geology, 9, 226-244.

Smith, I.F. 2005. Editor: Digital Geoscience Spatial Model Project. Final Report. British Geological Survey Occasional Publication, 9, 56pp.

Stedman, C. 1988. Namurian E1 tectonics and sedimentation in the Midland Valley of Scotland: rifting versus strike-slip influence. In; Besly, B M, \& Kelling, G (Eds.): Sedimentation in a synorogenic basin complex: the Upper Carboniferous of northwest Europe. (Glasgow: Blackie \& Son.), 242-254.

Stephenson, D., Loughlin, S.C., Millward, D., Waters, C.N. \& Williamson, I. T. 2003. Carboniferous and Permian Igneous Rocks of Great Britain North of the Variscan Front. Geological Conservation Review Series Number 27, Joint Nature Conservation Committee, Peterborough.

Sylvester, A. G., 1988. Strike-slip faults. Geological Society of America Bulletin, 100, 1666-1703.

Thomson, M.E.,1978. IGS studies of the geology of the Firth of Forth and its Approaches. Report of the Institute of Geological Sciences Great Britain 77/17. HMSO London, ISBN 0118840657. 
Tulloch, W. \& Walton, H.S. 1958. The Geology of the Midlothian Coalfield. Memoirs of the Geological Survey.

Underhill, J.R. 2003. The tectonic and stratigraphic framework of the United Kingdom's oil and gas fields. In: Gluyas, J.G. \& Hichens, H.M (Eds.): United Kingdom oil and gas fields. Memoir of the Geological Society, 20, 17-59.

Underhill, J.R. \& Brodie, J.A, 1993. Structural geology of Easter Ross, Scotland implications for movement on the Great Glen Fault zone. Journal of the Geological Society, 150, 515-527.

Underhill, J.R., Gayer, R.A., Woodcock, N.H., Donnelly, R., Jolley, E. \& Stimpson, I.G. 1988. The Dent Fault, northern England - reinterpreted as a major oblique slip fault zone. Journal of the Geological Society, 145, 313-316.

Vincent, C.J. \& Rowley, W.J. 2004. Thermal modeling in the Midland Valley of Scotland using BasinMod and HotPot: British Geological Survey report IR/04/144.

Wilcox, R.E., Harding, T.P. \& Seely, D.R. 1973. Basic Wrench tectonics. AAPG Bulletin, 57, 74-96. 


\section{Figure Captions:}

Fig.1: Summary Geological map of the Midland Valley Basin, Scotland with major faults and folds, six figure National Grid references and latitude/longitude shown. The basin is defined by the Highland Boundary and Southern Uplands Faults and is dominated internally by the occurrence of numerous N-S trending folds including the Clackmannan Syncline (CS), the Burntisland Anticline (BA), Midlothian-Leven Syncline (MLS).

Fig.2: Carboniferous Stratigraphy of the Midland Valley Basin (after Browne et al., 1999) and with stratigraphic level of seismic picks shown by arrow on right hand side. The timescale subdivisions follow revisions accepted by the Subcommission on Carboniferous Stratigraphy (SCCS) and ratified by the International Commission on Stratigraphy (ICS) and The International Union of Geological Sciences (IUGS) (Holliday \& Molyneaux, 2006). The Holkerian to Arundian substage boundaries are not shown because they are not recognised by biostratigraphy in the MVS.

Fig.3: Seismic and Well Database consisting of Conoco’s 2-D seismic lines from the Firth of Forth, Burmah, Anvil and Pentex 2-D seismic lines from the Earl's Seat Anticline in Fife and all available oil exploration well and other coalfield and BGS borehole data. Location of the seismic lines used in Figures 5-8 are highlighted.

Fig.4: Summary well-log for Conoco’s 25/26-1 (Firth of Forth-1) well highlighting the main identifiable stratigraphic horizons used to constrain the seismic interpretation (Modified after 
Ritchie et al., 2003). Top Passage Formation pick and Top Upper Limestone Formation pick are above sea level in 25/26-1. The Top Anstruther Formation (Base Pittenween Formation) marker has been used to contour the maps because it is present across the whole area.

*Fig.5: WSW-ENE striking seismic line depicting the subsurface nature of the MidlothianLeven Syncline beneath the Firth of Forth. The section is constrained by the 25/26-1 well and demonstrates the open asymmetric fold geometry that characterises the regional structure.

Fig.6: WSW-ENE striking seismic line depicting the subsurface nature of the MidlothianLeven Syncline beneath the Firth of Forth. The section is constrained by the 25/26-1 well and demonstrates the open asymmetric fold geometry that characterises the regional structure.

*Fig.7: WSW-ENE striking seismic line depicting the subsurface nature of the MidlothianLeven Syncline beneath the Firth of Forth. The section is constrained by the 25/26-1 well and demonstrates the open asymmetric fold geometry that characterises the regional structure.

*Fig.8: NNW-SSE striking seismic line depicting the subsurface nature of the MidlothianLeven Syncline beneath the Firth of Forth. The section is constrained by the 25/26-1 well and demonstrates the open asymmetric fold geometry that characterises the regional structure.

Fig.9: Contoured structure map for the Top Anstruther Formation (Base Pittenweem Formation). The map highlights the doubly-plunging, canoe-shaped form of the Leven Syncline. 
Fig.10: Summary map integrating the outcrop and subcrop data from offshore waters of the Firth of Forth with data obtained from neighbouring land areas. Onshore data modified and simplified after BGS (1971a, 1971b, 1980, 1983, 1998, 1999, 2003).

Fig.11: Geological map of the Earl's Seat Anticline, Fife modified after BGS (1999). The structure is one of a number of SW-NE trending, transected folds that occur throughout the basin. The map shows the location of the Milton of Balgonie-1 well and the line of section used in Fig.12.

Fig.12: Uninterpreted seismic reflection profile and interpreted geological cross-section across the Earl's Seat Anticline, Fife. The section demonstrates the important role that postdepositional compression along steeply dipping, upward diverging reverse faults play in the evolution of the basin. (TD= total depth of Milton of Balgonie well).

Fig.13: Geological map of the Westfield area, Fife simplified after BGS (1971b, 1999) with fold axes on the Westfield Shale Coal from BGS (1996). Its precise location is given on Fig.10.

Fig.14: Photograph and line drawing interpretation of the Westfield Coalfield opencast site showing the field evidence for spectacular thickening in the core regions of the syncline during deposition of the Passage Formation (shown in yellow). The stratigraphic and sedimentological relationships demonstrate the effects of pronounced syn-sedimentary 
growth folding that affected the area during Namurian times. The view is looking NNE with dumper trucks for scale. CBGS photograph.

Fig.15: Photograph and line drawing interpretation of the East Ochil Fault, Westfield, showing. The fact that the normal fault cuts strata in the syncline up to Westphalian in age and a latest Carboniferous intrusion of the MVS tholeiitic sill complex does not bake adjacent hangingwall strata thus demonstrates the direct field evidence for post-depositional, post-intrusion Permian E-W striking extensional faulting in the basin. (CBGS photograph).

Fig.16: Map depicting the highly folded nature of Carboniferous sediments adjacent to the Ardross Fault on the Fife Coast. The obliquity between the dominantly NNE-SSW striking folds and the ENE-WSW faults with which they are directly associated supports the view that the deformation results from dextral strike-slip on the latter.

Fig.17: Oblique aerial photograph (looking approximately NE) showing the NE-SW striking St Monans Syncline (axis highlighted in blue) affecting the Middle Mississippian (Brigantian) Lower Limestone Formation, (CBGS photograph number D02796). The NEplunging tight fold structure is one of a number of folds found along the East Fife coast that are interpreted to have formed as a result of strike-slip deformation on intra-basinal faults affecting the Midland Valley during the Carboniferous.

Fig.18: Cross-section showing the asymmetric, south-easterly verging footwall syncline developed in the immediate footwall to the steeply-dipping, contractional, Pentland Fault. 
The structural and stratigraphic relationships associated with the Midlothian Syncline demonstrate that the Pentland Fault represents a post-depositional reverse fault formed in Late Carboniferous (Variscan) times. Although impossible to determine from the field evidence, it is thought that the fault may also have been reactivated during subsequent Cenozoic uplift.

Fig.19: Schematic cartoon illustrating the structural controls on stratigraphic architecture in the Midland Valley during the Carboniferous. The model highlights the connection between observed structural styles and those developed in analogue models and field exposures associated with dextral strike-slip on boundary faults. The deformation is consistent with basic wrench tectonic principles (e.g. Wilcox et al., 1973; Sylvester, 1988)

Fig.20: Field photograph depicting the bituminous Balm or "Oyly” Well in the grounds of St Catherine’s House, Mortonhall, South Liberton Edinburgh (Grid Reference: NT273684). The feature represents the site of an active oil seep found along the trace of the Pentland Fault (C) BGS photograph). Its occurrence demonstrates the fact that source rock maturity has prevailed and the role that intra-basinal faulting in this case, the Pentland Fault, has had in controlling oil migration. Oil from the seep was used as balming oil for the treatment of skin ailments until the early $20^{\text {th }}$ Century. The well has historical significance too, being a place of pilgrimage for many Scottish monarchs including James IV, who visited it in 1504 and by James VI (James I of Great Britain), who had it protected by a well in 1617. Although Cromwell's troops destroyed the well in 1650, it was restored in 1889. 
Fig.21: Schematic burial history plot for the West Lothian Oil Shale Formation, a component part of the Strathclyde Group in the Firth of Forth area. The plot depicts curves constructed for different parts of the Midlothian-Leven Syncline and demonstrates that oil-shales within axial parts of the fold first reached maturity in the Late Carboniferous. The oil-shales also appear to have remained mature during their subsequent history of uplift and burial and are even locally mature in the core of the Leven Syncline at the present-day.

Fig.22: Map depicting the areal extent of the present-day kitchen area for the most prolific oil-shale source rocks of the West Lothian Oil Shale Formation that occur within the Strathclyde Group. The map highlights the hydrocarbon migration pathways in and around the Leven Syncline beneath north-western parts of the Firth of Forth.

Fig.23: Cartoon depicting the main elements of the petroleum system in the eastern Midland Valley of Scotland. The diagram highlights the main play type, namely up-dip migration and charge of flanking, reservoir-bearing anticlines lying on the eastern flank of the MidlothianLeven synclinal fold, the buried core of which contains the oil-shale source rock kitchen. 


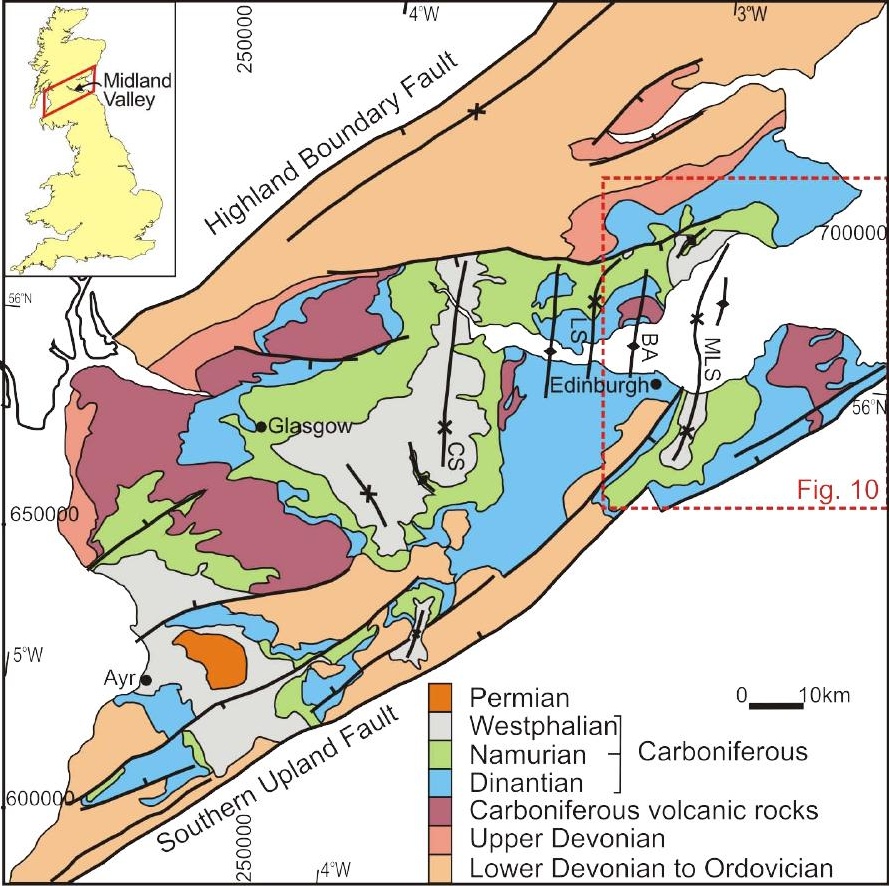




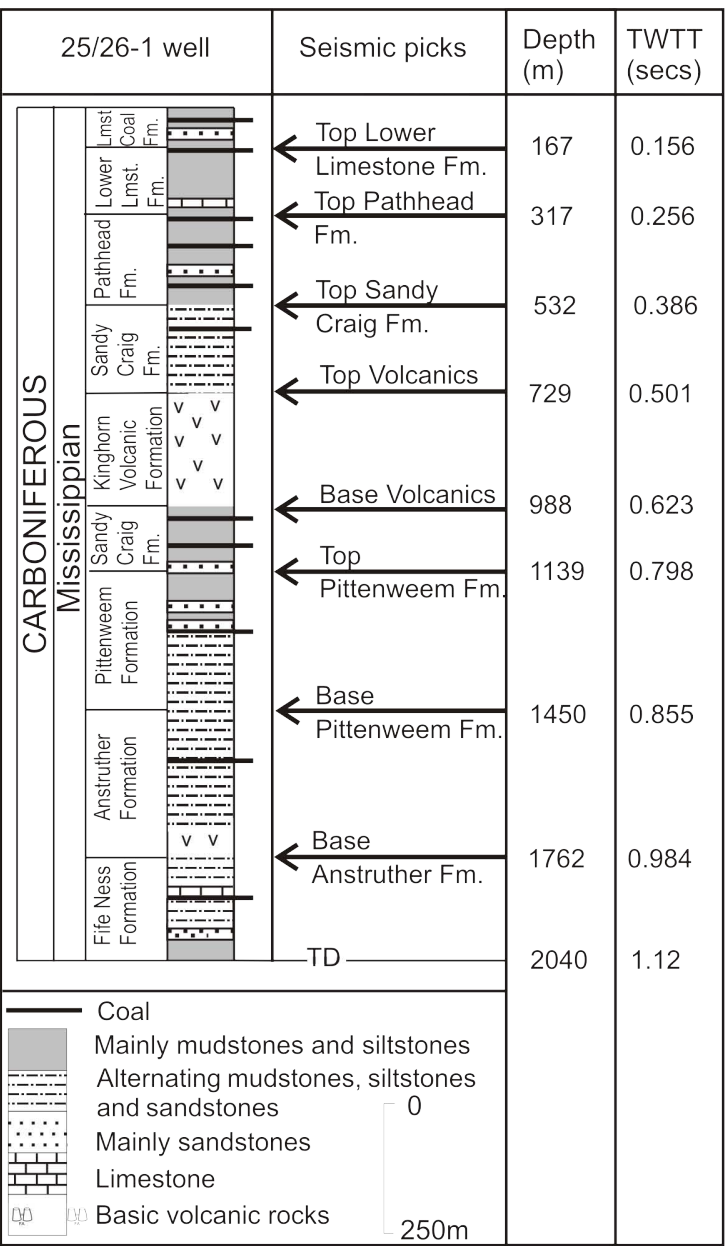




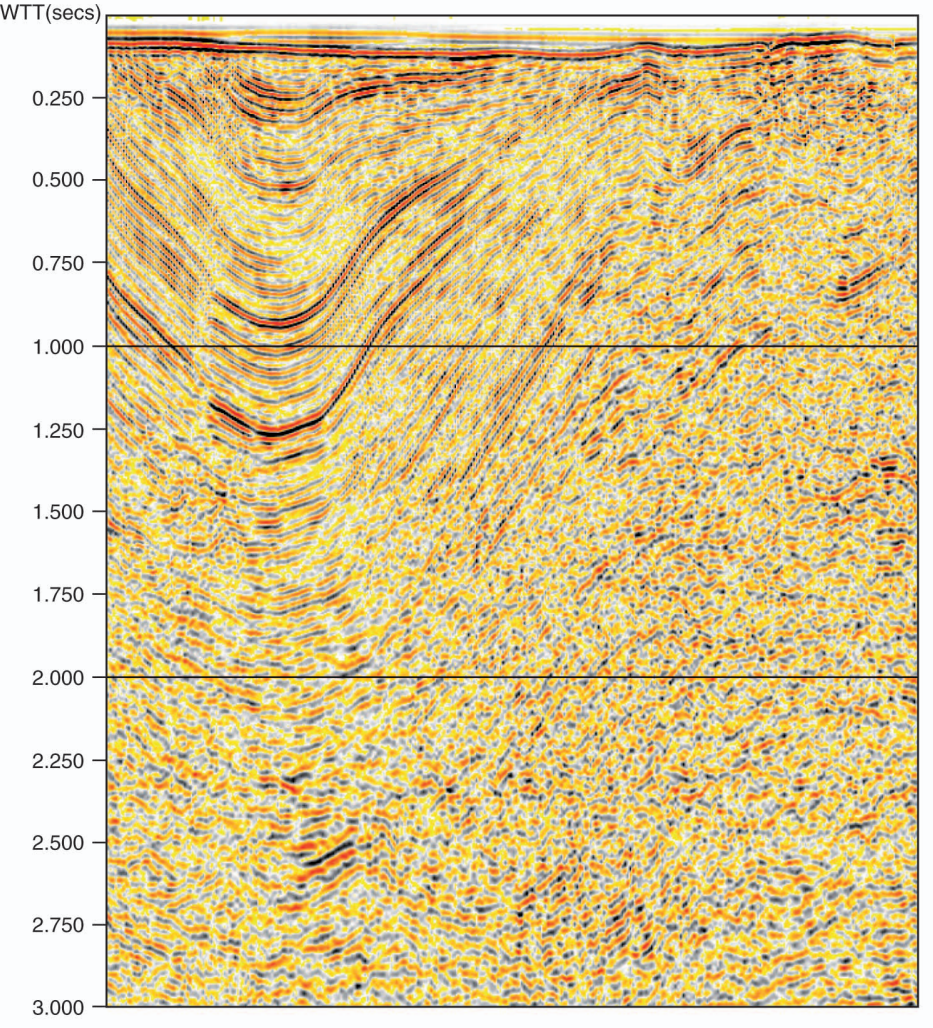

Crossing seismic line Fig. 8

wsw

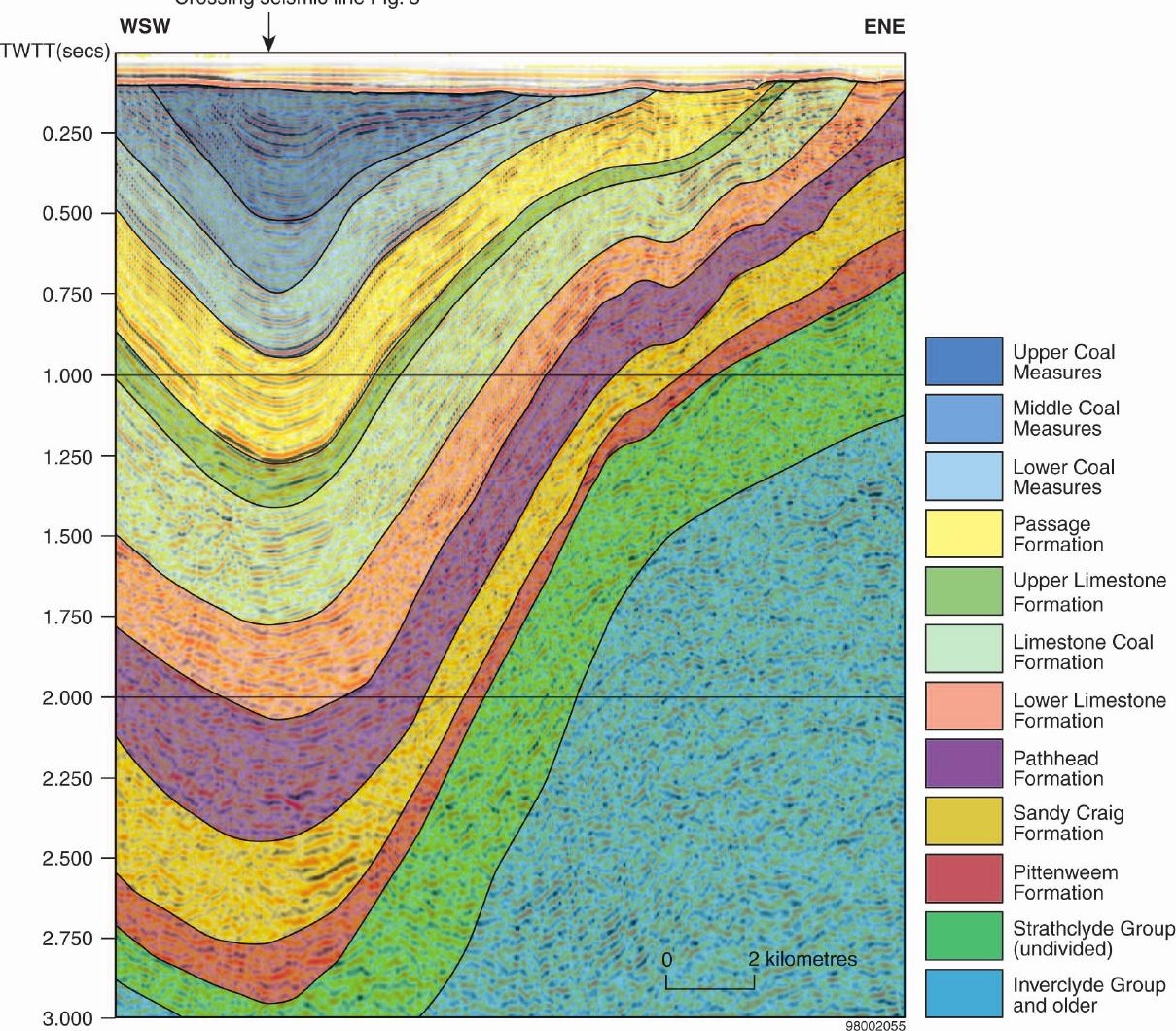




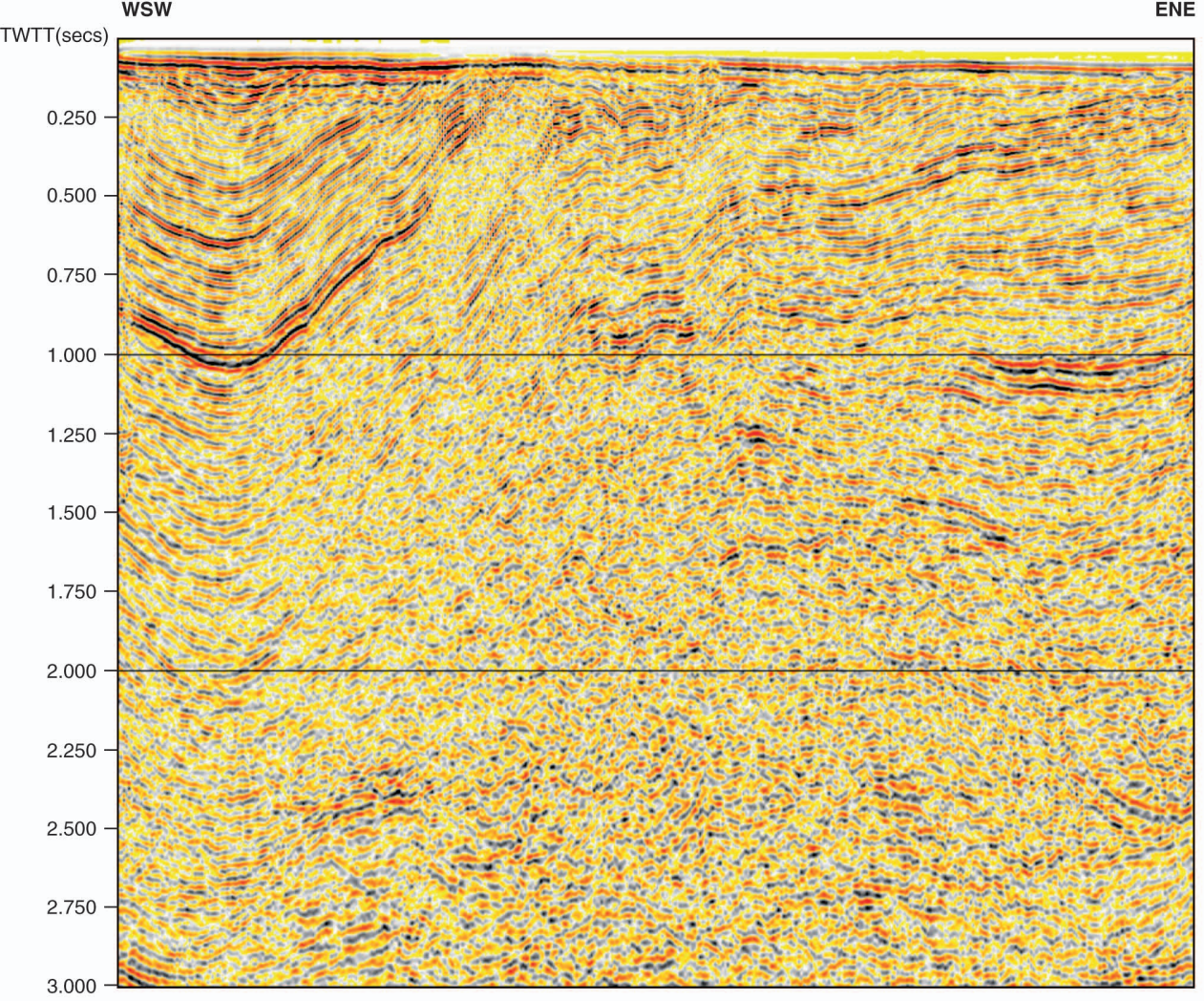



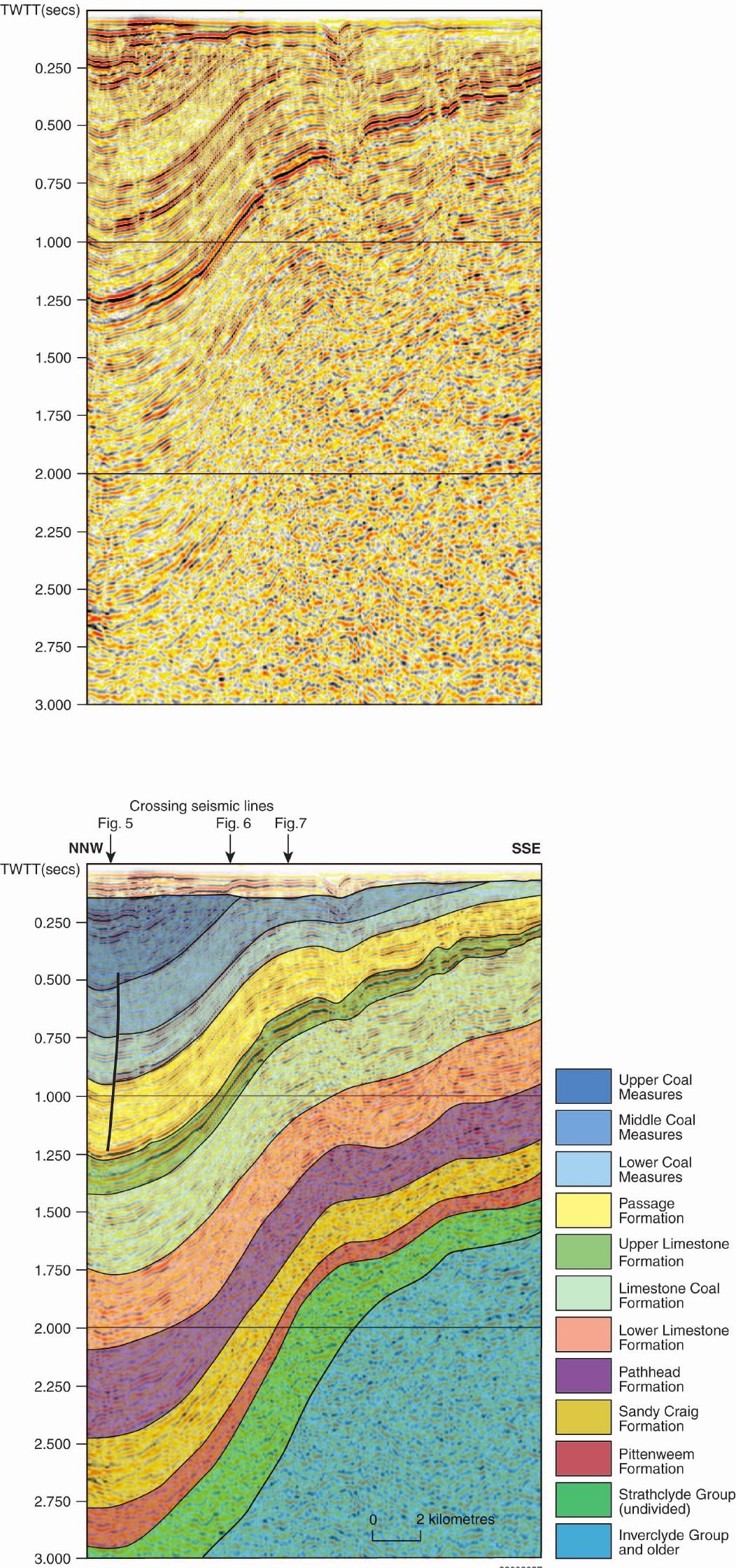


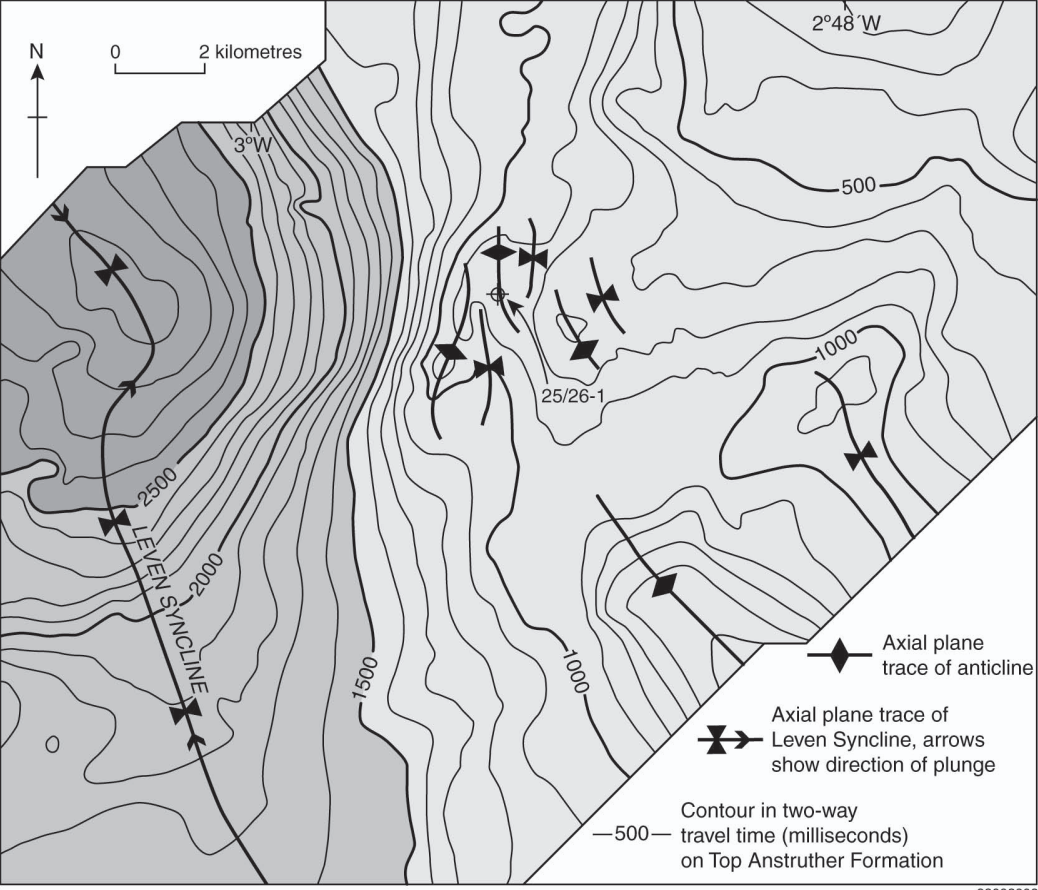

98002009 


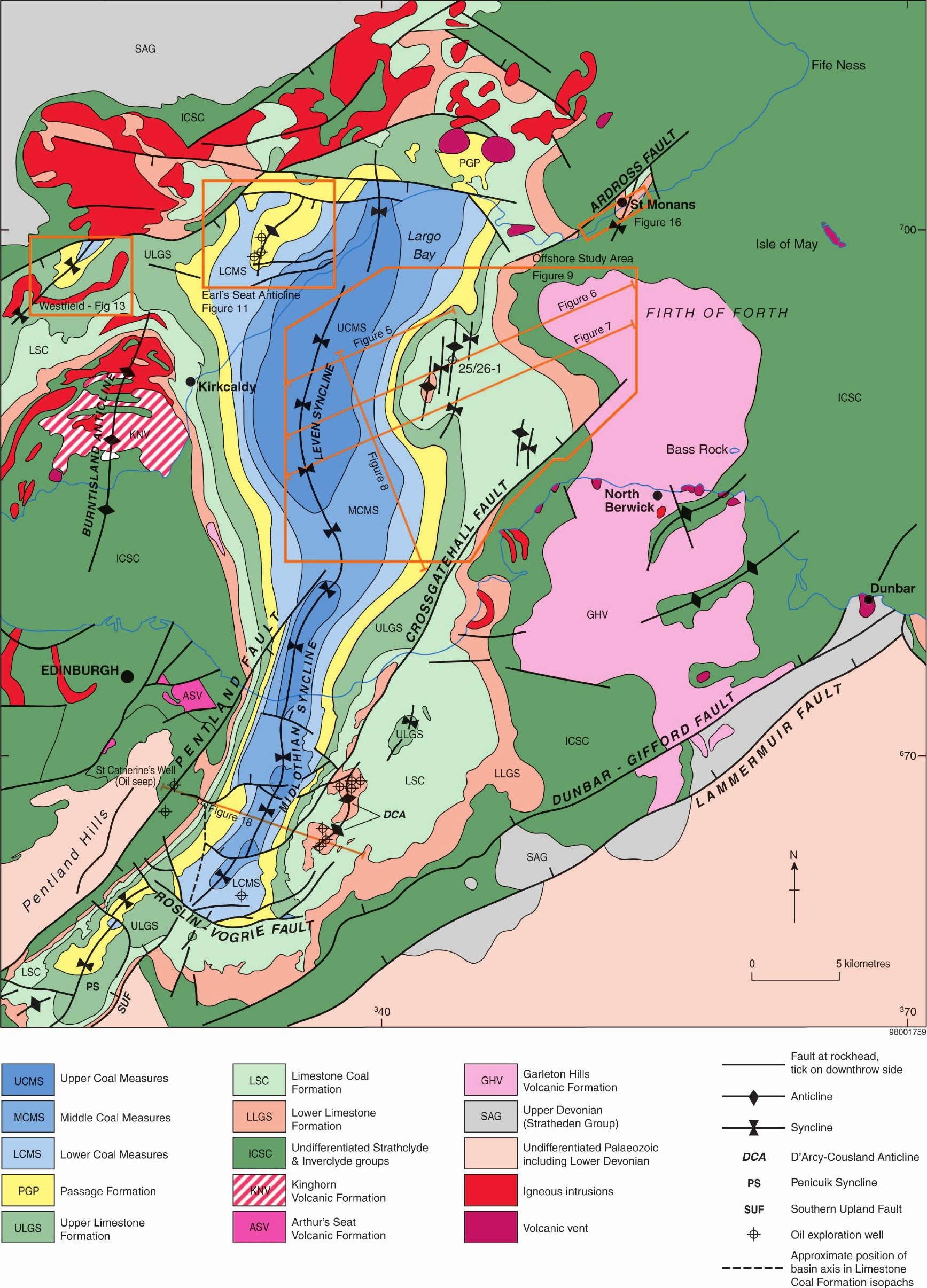


Eis
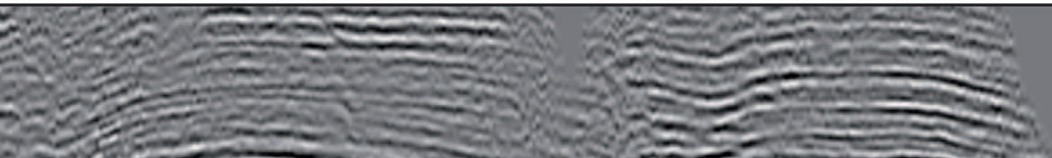

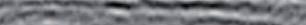

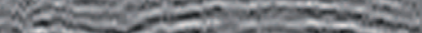
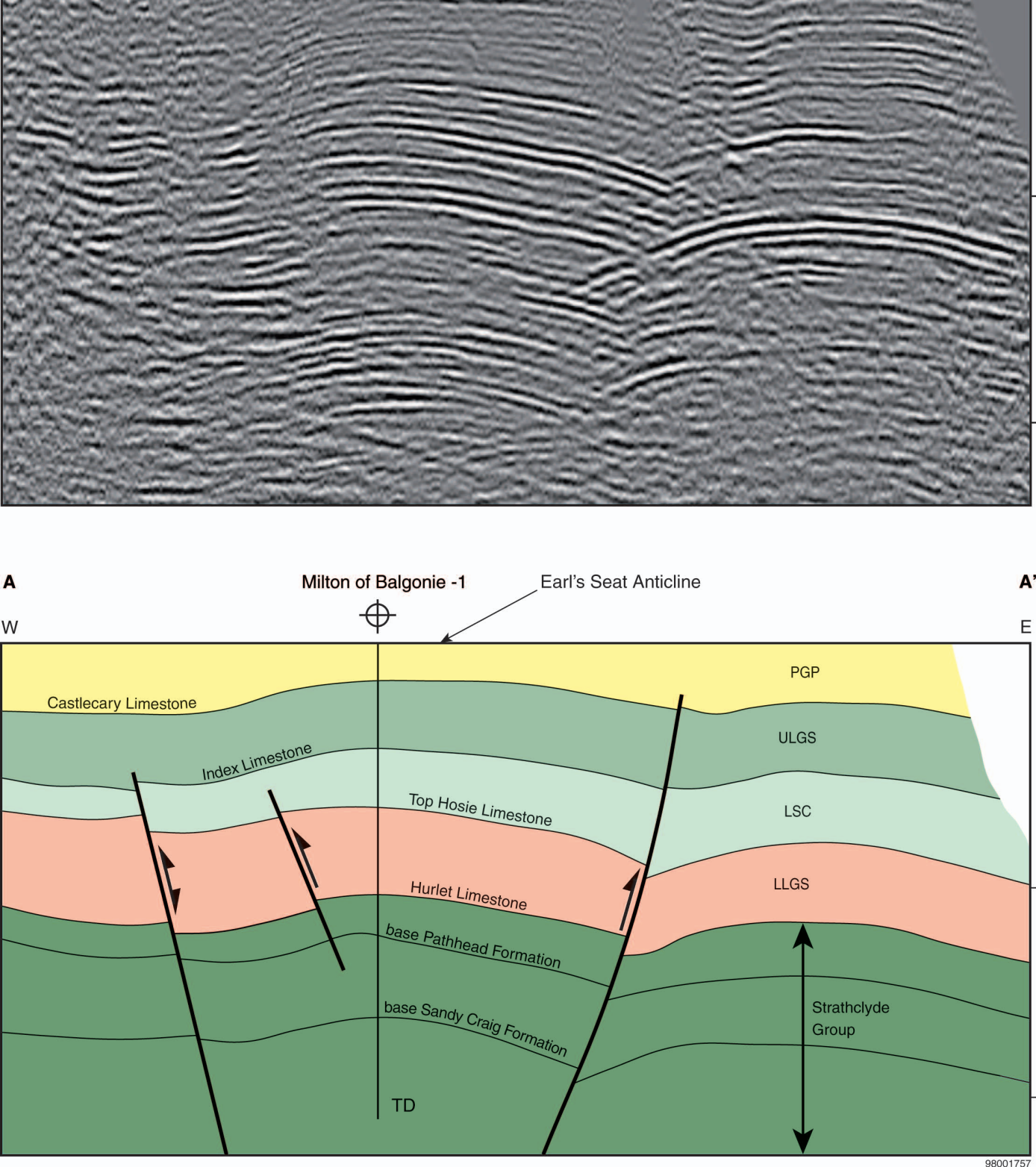


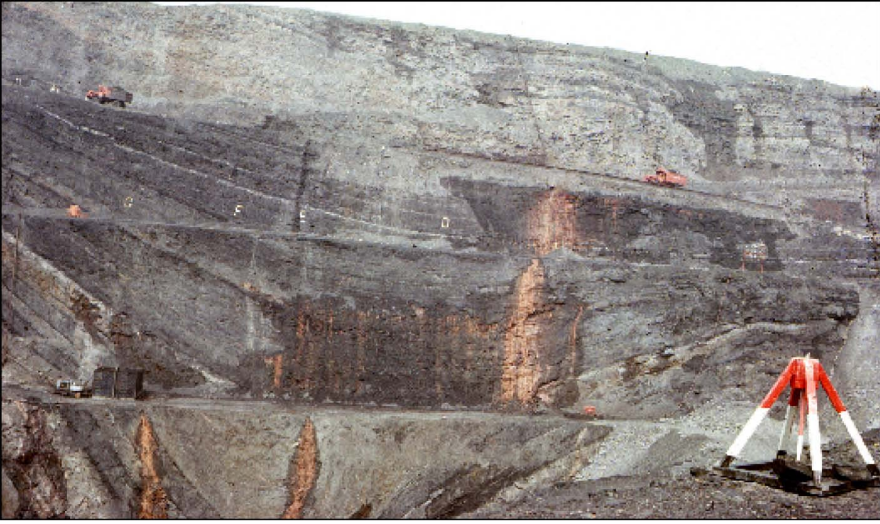

ESE

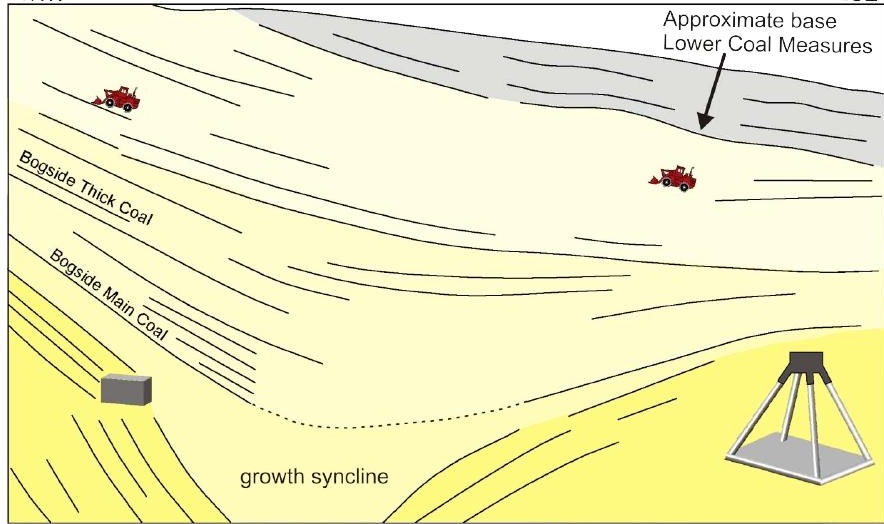




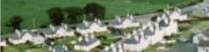

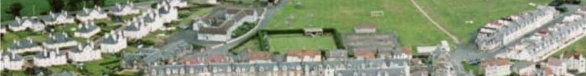
4\%. 3 .

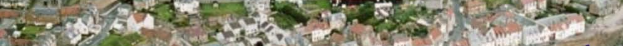
We

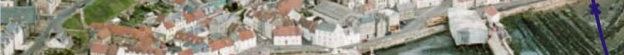
6. (3). G.

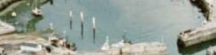
(1) $\frac{3}{25}=$ a.

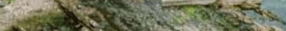
in $>-1$ ris

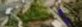
20 $+$ (x)

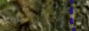
ate (4) E⿱一⿻上丨+口 ass andente.
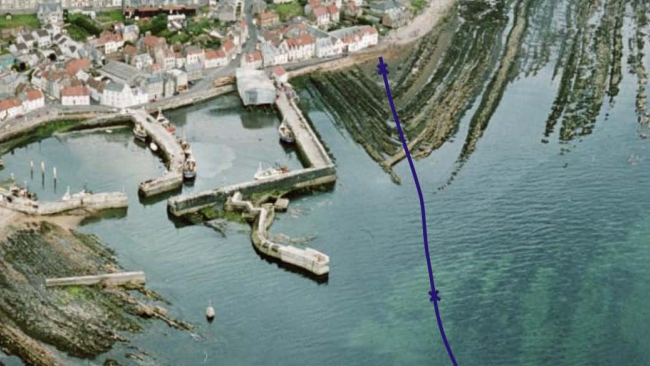


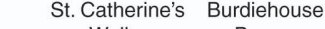

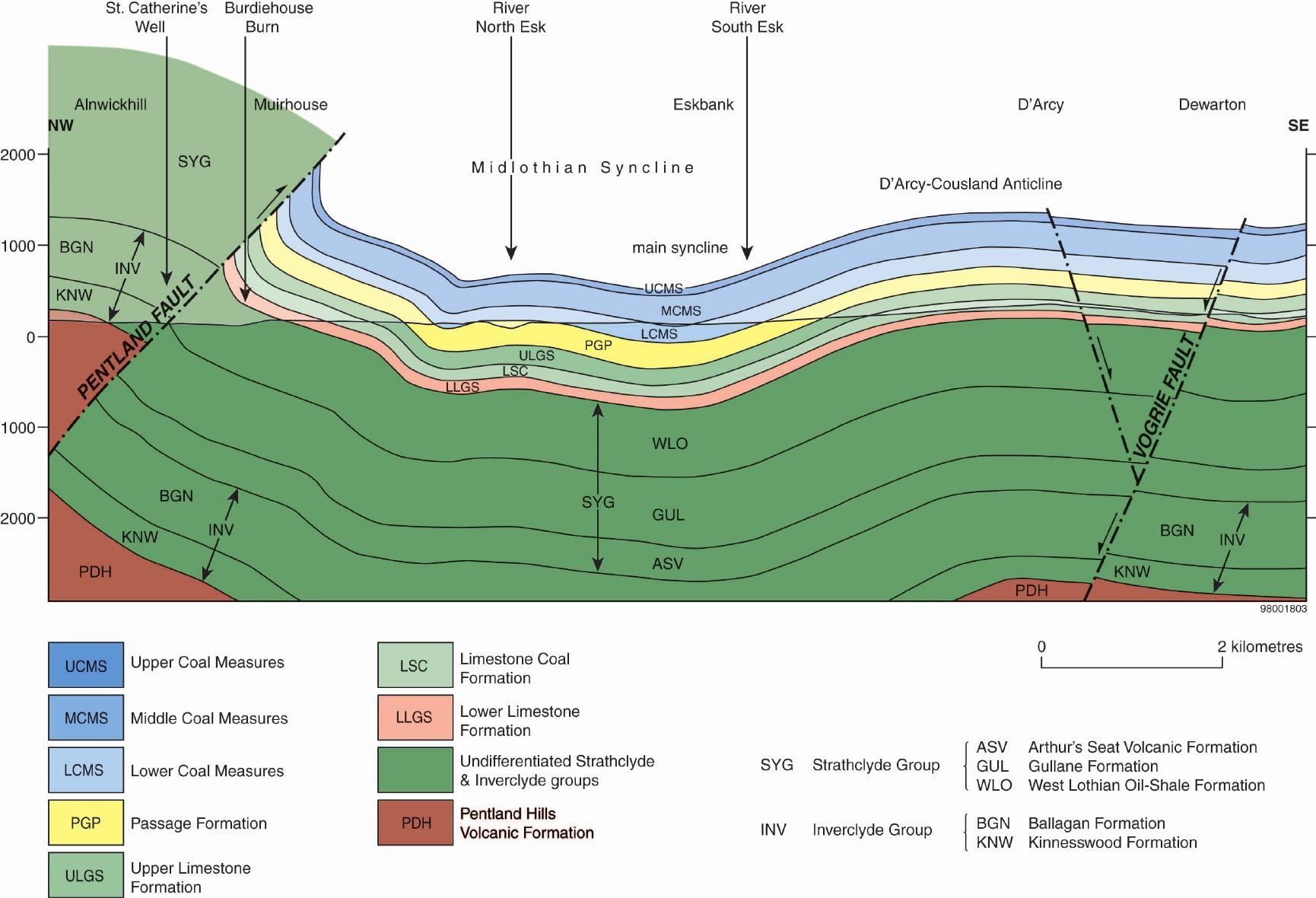

North Esk
South Esk

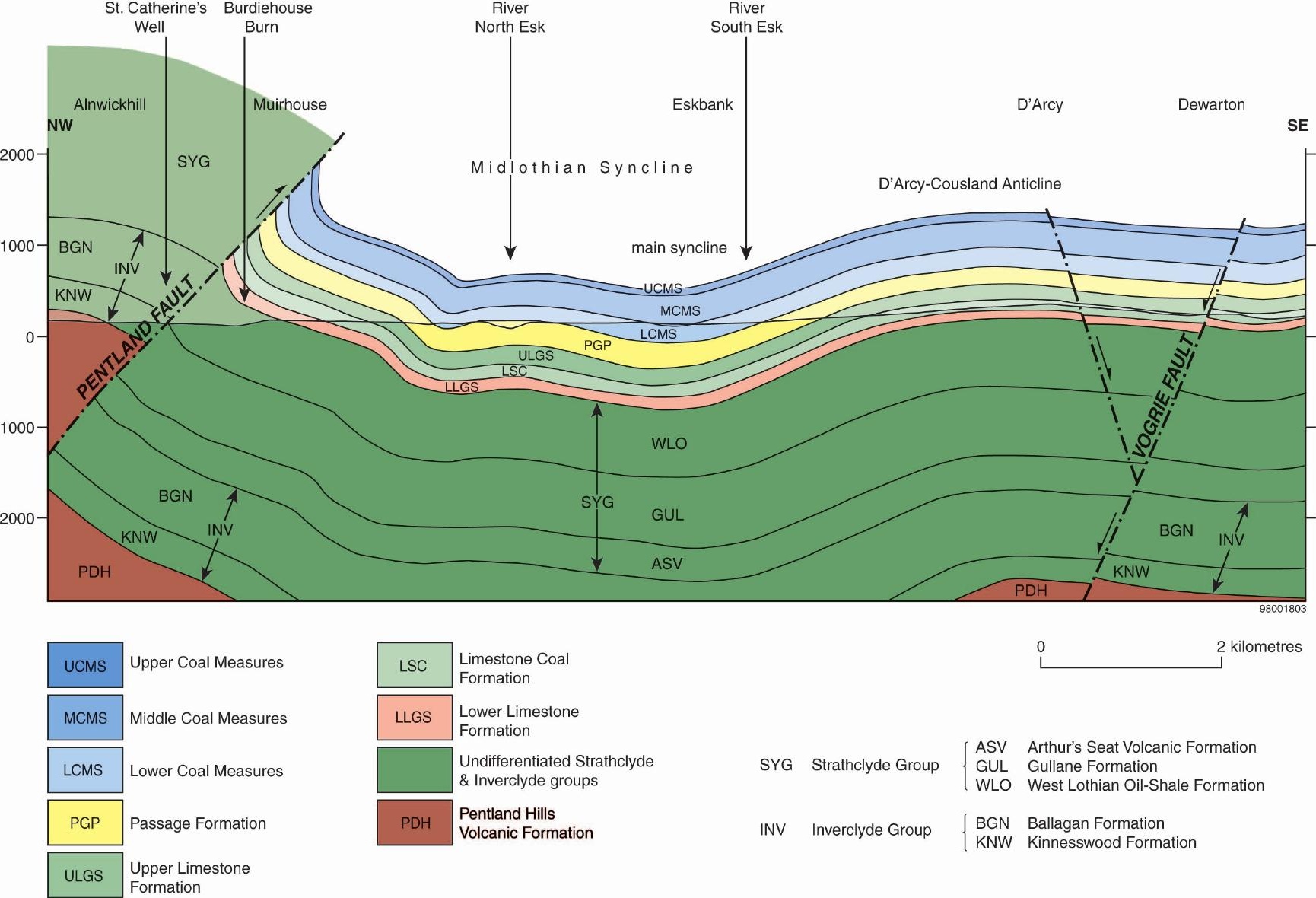





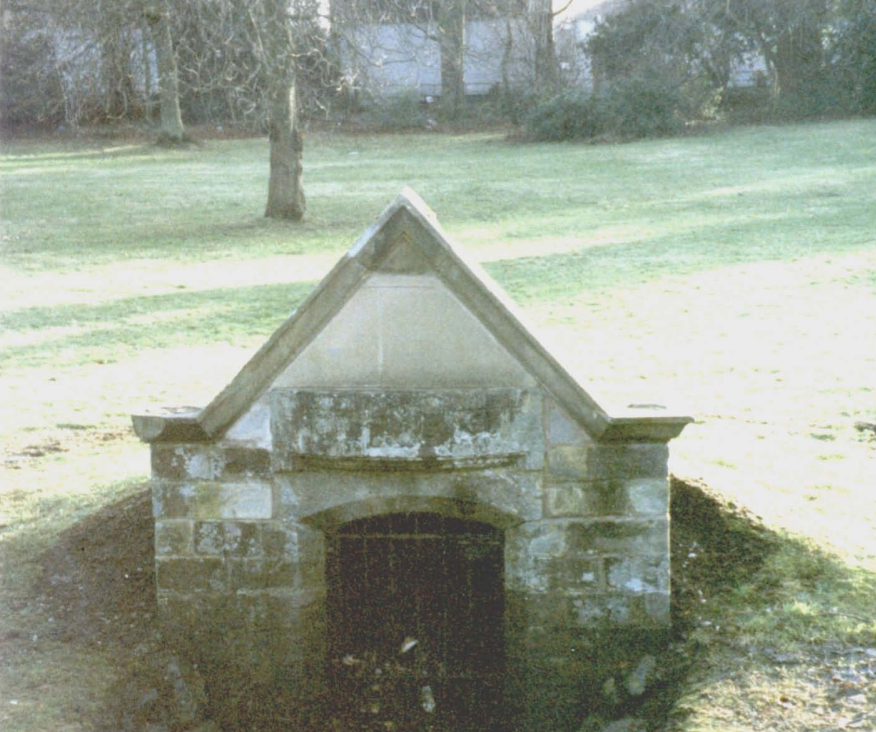
6. and

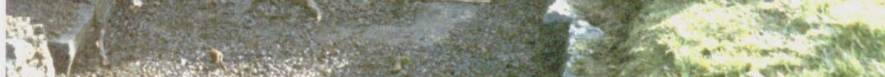

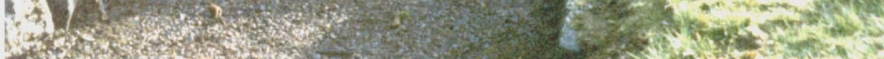

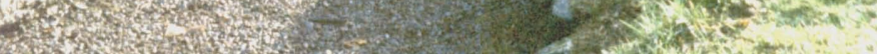

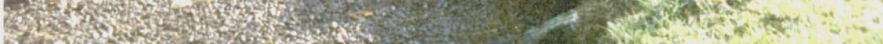

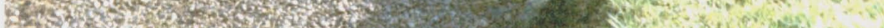
Wy- 


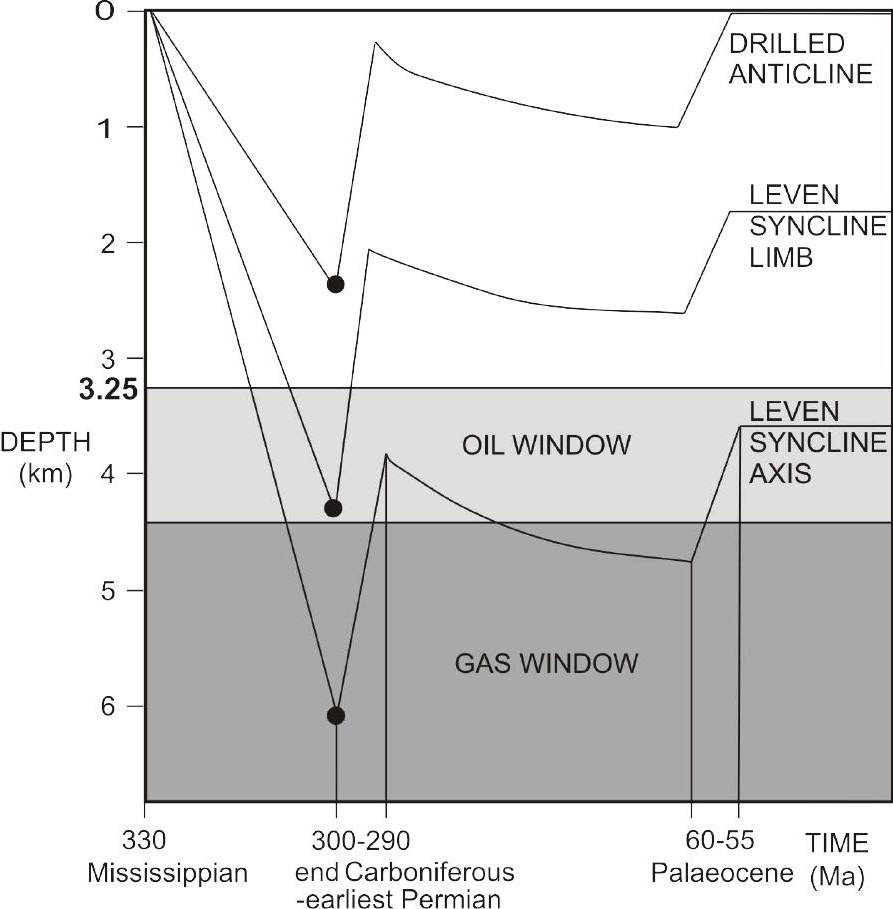




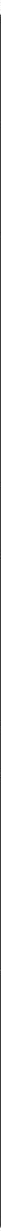

Present day oil kitchen area at Base Pittenweem Formation (Base West Lothian Oil-Shale).

$>$ Present day oil migration pathways

Contours in metres below OD at base Pittenweem Formation 


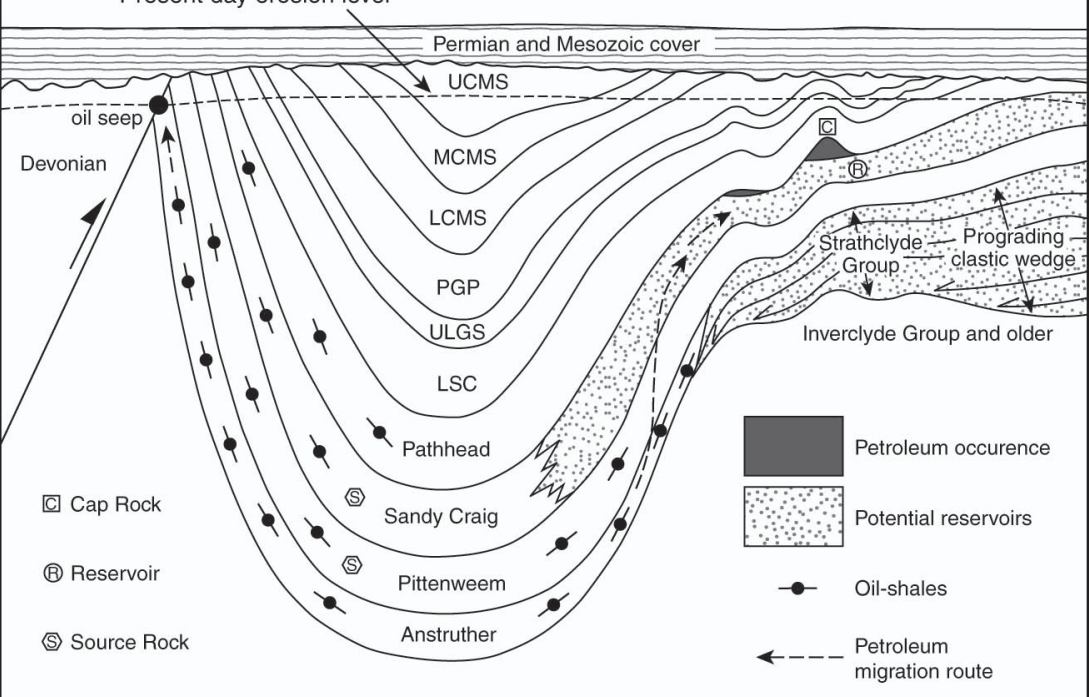

